\title{
Late Albian paleoceanography of the western subtropical North
} Atlantic

\author{
Maria Rose Petrizzo, ${ }^{1}$ Brian T. Huber, ${ }^{2}$ Paul A. Wilson, ${ }^{3}$ and Kenneth G. MacLeod ${ }^{4}$ \\ Received 9 January 2007; revised 4 July 2007; accepted 7 November 2007; published 8 March 2008.
}

[1] A late Albian-early Cenomanian record ( 103.3 to $99.0 \mathrm{Ma})$, including organic-rich deposits and a $\delta^{13} \mathrm{C}$ increase associated with oceanic anoxic event 1d (OAE 1d), is described from Ocean Drilling Program sites 1050 and 1052 in the subtropical Atlantic. Foraminifera are well preserved at these sites. Paleotemperatures estimated from benthic $\delta^{18} \mathrm{O}$ values average $\sim 14^{\circ} \mathrm{C}$ for middle bathyal Site 1050 and $\sim 17^{\circ} \mathrm{C}$ for upper bathyal Site 1052 , whereas surface temperatures are estimated to have ranged from $26^{\circ} \mathrm{C}$ to $31^{\circ} \mathrm{C}$ at both sites. Among planktonic foraminifera, there is a steady balance of speciation and extinction with no discrete time of major faunal turnover. OAE $1 \mathrm{~d}$ is recognized on the basis of a $1.2 \%$ o $\delta^{13} \mathrm{C}$ increase $(\sim 100.0-99.6 \mathrm{Ma})$, which is similar in age and magnitude to $\delta^{13} \mathrm{C}$ excursions documented in the North Atlantic and western Tethys. Organic-rich "black shales" are present throughout the studied interval at both sites. However, deposition of individual black shale beds was not synchronous between sites, and most of the black shale was deposited before the OAE 1d $\delta^{13} \mathrm{C}$ increase. A similar pattern is observed at the other sites where OAE $1 \mathrm{~d}$ has been recognized indicating that the site(s) of excess organic carbon burial that could have caused the $\delta^{13} \mathrm{C}$ increase has (have) yet to be found. Our findings add weight to the view that OAEs should be chemostratigraphically $\left(\delta^{13} \mathrm{C}\right)$ rather than lithostratigraphically defined.

Citation: Petrizzo, M. R., B. T. Huber, P. A. Wilson, and K. G. MacLeod (2008), Late Albian paleoceanography of the western subtropical North Atlantic, Paleoceanography, 23, PA1213, doi:10.1029/2007PA001517.

\section{Introduction}

[2] The mid-Cretaceous was a time of transition in the ocean-climate system. Beginning in the Aptian ( 120 Ma), outgassing associated with high rates of ocean crust production and off-axis volcanism contributed to a greenhouse world of rising sea level and global warming with maximum sea surface paleotemperatures reached during the early Turonian ( 92 Ma) [Clarke and Jenkyns, 1999; Huber et al., 1995, 2002; Norris et al., 2002; Wilson et al., 2002]. Previous foraminiferal $\delta^{18} \mathrm{O}$ studies of samples from the subtropical western North Atlantic indicate that middle bathyal waters (depth around $1000 \mathrm{~m}$ ) were $9^{\circ} \mathrm{C}$ to $10^{\circ} \mathrm{C}$ in the early Albian, warmed to about $15^{\circ} \mathrm{C}$ during the late Albian, and then became very warm in the latest Cenomanian and early Turonian when temperatures reached $19^{\circ} \mathrm{C}$ [Huber et al., 2002]. Comparison of sea surface temperature estimates from this region (Ocean Drilling Program (ODP) Site 1050) and southern high-latitude sites (Deep Sea Drilling Project (DSDP) Site 511; ODP Site 690) suggests only a $4^{\circ} \mathrm{C}$ difference during the late Albian with tropical

\footnotetext{
${ }^{1}$ Dipartimento di Scienze della Terra "Ardito Desio", Università di Milano, Milan, Italy.

${ }^{2}$ Department of Paleobiology, Smithsonian Museum of Natural History, Washington, D.C., USA.

${ }^{3}$ School of Ocean and Earth Science, National Oceanography Centre, Southampton, UK.

${ }^{4}$ Department of Geological Sciences, University of Missouri, Columbia, Missouri, USA.

Copyright 2008 by the American Geophysical Union. 0883-8305/08/2007PA001517
}

surface temperatures at least as warm as today [Wilson and Norris, 2001] and high-latitude surface temperatures much warmer than today [Huber et al., 1995].

[3] Here we present high-resolution stable isotope data across a thick section of the upper Albian-lower Cenomanian continental slope and rise sediments recovered from Blake Nose at ODP sites 1050 (2296 m water depth) and 1052 (1345 m water depth) located in the western North Atlantic (Figure 1). Depths during the late Albian and Cenomanian were about $800 \mathrm{~m}$ shallower [Norris et al., 1998]. Sites 1050 and 1052 are located within about $30 \mathrm{~km}$ of one another, and their paleolatitude is estimated to have been $\sim 25^{\circ} \mathrm{N}$ [Ogg and Bardot, 2001].

[4] At both sites, black and green laminated claystone (black shales) are interbedded with chalk, clayey limestone with foraminifera and quartz, and clayey siltstone. On the basis of their age and a $>1.2 \%$ carbon isotopic excursion measured at Site 1052 [Wilson and Norris, 2001] these late Albian black shales have been interpreted as the local expression of oceanic anoxic event (OAE 1d), one of a series of generally brief $(<1 \mathrm{Ma})$ but large perturbations of the Cretaceous global carbon cycle associated with common organic-rich deposits and positive $\delta^{13} \mathrm{C}$ excursions [e.g., Schlanger and Jenkyns, 1976; Arthur et al., 1990; Thurow et al., 1992; Bralower et al., 1994; Jenkyns and Wilson, 1999]. A discrete latest Albian OAE (OAE 1d) in the upper part of the planktonic foraminiferal Rotalipora appenninica zone was first proposed by Erbacher and Thurow [1997] and was correlated with rhythmically bedded organic-rich black shale of the Breistoffer event [Bréhéret, 1988, 1997] in Vocontian Basin (southern France). OAE 1d has subse- 


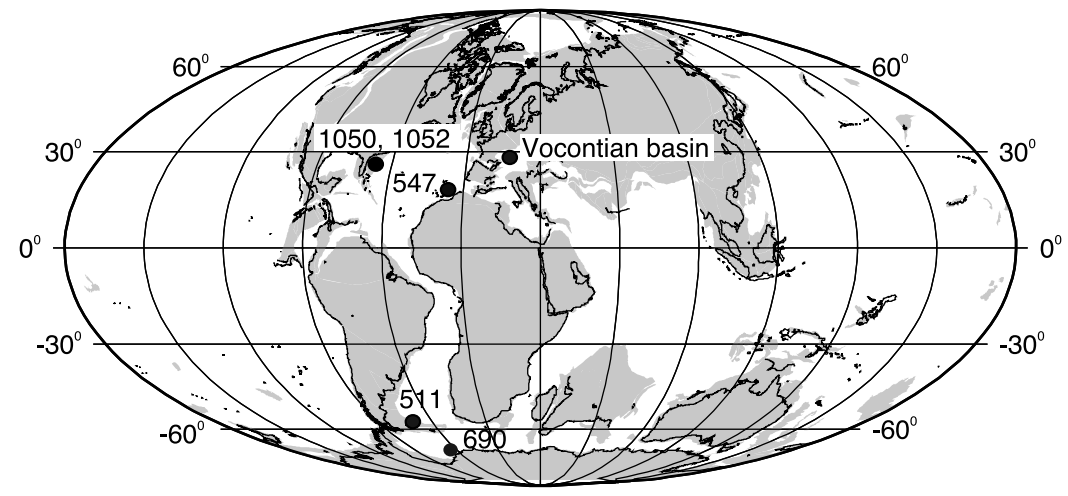

Figure 1. Paleogeographic reconstruction for the late Albian (101 Ma) according to Hay et al. [1999] showing the localities discussed in this study.

quently been reported at localities across western Tethys [Strasser et al., 2001; Coccioni, 2001; Giraud et al., 2003; Hofmann et al., 2000; Bornemann et al., 2005] and at DSDP Site 547 on the Moroccan margin [Leckie, 1984; Nederbragt et al., 2001] (Figure 1). Correlative, but less well developed, black shales have also been reported in the South Atlantic, southern Indian, and eastern Pacific Ocean basins [Leckie et al., 2002].

[5] At DSDP Site 547, uppermost Albian organic-rich sediments assigned to OAE $1 \mathrm{~d}$ are associated with a major phase of biotic turnover affecting the planktonic foraminifera [Nederbragt et al., 2001] and radiolarians [Erbacher et al., 1996]. Notable among planktonic foraminifera assemblage datums are, from oldest to youngest, the first appearance of the genus Planomalina, the extinction of Ticinella and Biticinella, and the appearance of Praeglobotruncana. However, only minor changes in nannofossil assemblages and insignificant changes among benthic foraminifera were recognized at this site [Nederbragt et al., 2001]. In contrast, nannofossil data from the northwestern North Atlantic Ocean (Blake Nose) reveal that a major radiation occurred in the genus Eiffellithus [Watkins and Bergen, 2003], and nine taxa with morphological features that suggest adaptation to a preferred position in the water column became extinct within OAE 1d [Watkins et al., 2005].

[6] To investigate the possible causes of black shale formation at Blake Nose, this study (1) obtained a record of stable isotope change at two closely spaced sites in different water depths, (2) generated highly resolved chemostratigraphic and biostratigraphic correlations across upper Albian sediments recovered on Blake Nose against which paleoenvironmental trends can be compared, (3) documented the degree of turnover affecting the planktonic foraminifera across the OAE $1 \mathrm{~d}$ interval in the subtropical western North Atlantic, and (4) compared the pattern and timing of the $\delta^{13} \mathrm{C}$ shift at Blake Nose with that reported from the Vocontian Basin and at DSDP Site 547.

\section{Material and Methods}

[7] From the upper Albian-lower Cenomanian at sites 1050 and 1052 we analyzed over 400 samples (102 from
Hole $1050 \mathrm{C}$ and 309 from Hole 1052E) with a stratigraphic resolution of 20 to $30 \mathrm{~cm}$ where possible. Samples of about $10 \mathrm{~cm}^{3}$ were processed following procedures described by Petrizzo and Huber [2006].

[8] At Hole 1050C, samples are late Albian in age and span sample 26R-1, 7-9 cm to sample $31 \mathrm{R}-\mathrm{CC}$ (the base of cored interval) (Figure 2). This $57.53 \mathrm{~m}$ thick interval was assigned to subunit VIA [Norris et al., 1998] and consists of olive-gray nannofossil claystone alternating with laminated dark claystone (black shales). The claystone contains variable proportions of calcareous microfossils, neritic shell debris, and siliciclastic components. The laminated black shales are rich in pyrite and contain clay with varying proportions of calcareous microfossils, silt-sized quartz and feldspar, fish remains, and organic debris with up to $1.45 \mathrm{wt} \%$ total organic carbon (TOC) [Barker et al., 2001].

[9] At Hole 1052E we have analyzed samples from a $179.09 \mathrm{~m}$ stratigraphic interval of the late Albian-early Cenomanian spanning sample 39R-1, 147.5-149 $\mathrm{cm}$ to sample 58R-CC (the base of the cored interval) (Figure 2). Samples from core 39 and the upper two samples studied in section 40R-1 belong to the lower portion of subunit VA, which mainly consists of calcareous claystone and quartz silt claystone. Sample 1052E-40R-1, $124 \mathrm{~cm}$ occurs at the top of the sedimentary sequence assigned to subunit VB and consists of claystone alternating with laminated dark claystone (black shales) with up to $1.37 \mathrm{wt} \%$ TOC [Barker et al., 2001] and minor, lighter colored limestone. The color varies from light olive gray in the limestones to very dark olive gray in the black shale [Norris et al., 1998]. The stratigraphic sequence from sample $1052 \mathrm{E}-53 \mathrm{R}-5,30 \mathrm{~cm}$ to the base of the interval belongs to subunit VC [Norris et al., 1998] and is dominated by slightly to moderately bioturbated dark olive-gray sandy siltstones with wavy laminations. Minor lithologies include several quartz- and bioclast-rich grainstone intervals, very coarse to medium-fine-grained calcite-cemented sandstone in core $1052 \mathrm{E}-57 \mathrm{R}$, and a massive, crudely cross-bedded, very coarse grained to mediumfine-grained, peloid, bioclast grainstone with miliolids and lithic fragments containing up to $0.92 \mathrm{wt} \%$ TOC [Barker et al., 2001] in core 1052E-58R. 
Hole $1050 \mathrm{C}$
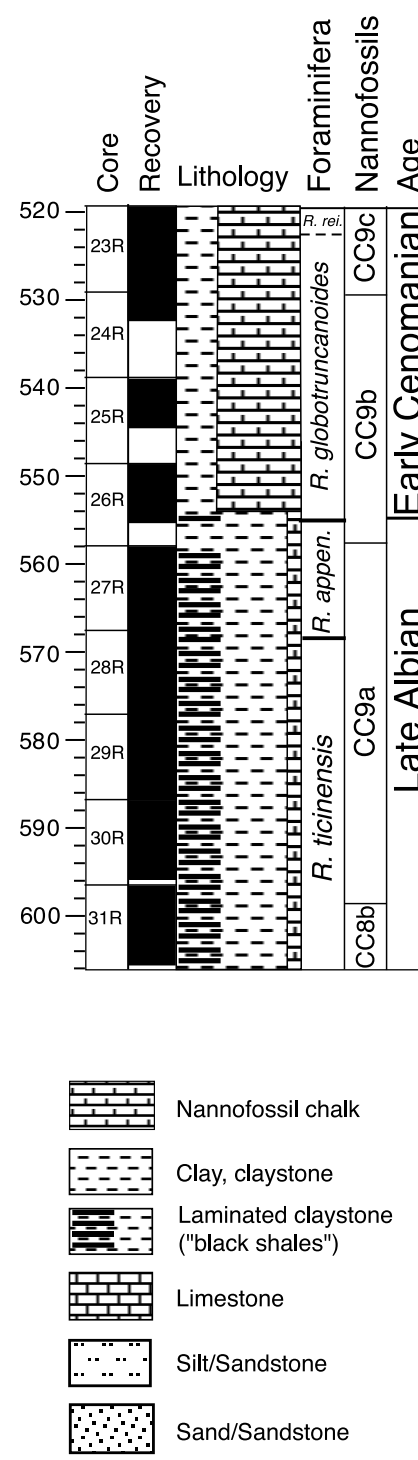

\section{Hole 1052E}

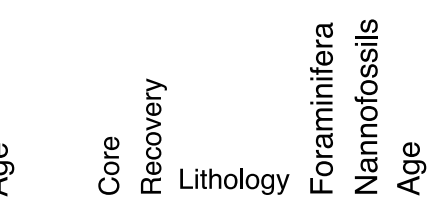

logic timescale of Gradstein et al. [2004]. Age assignments and references for calcareous plankton first and last appearance datums used to constrain the age-depth curve for both holes (Figure 3) are listed in Table 1.

[11] Rhythmically bedded organic-rich black shales occur at both sites (Figure 4). Their distribution and thickness were plotted using $0.5 \mathrm{wt} \%$ TOC as a minimum organic carbon content and comparing the TOC values with the core descriptions and visual observations of the core photos [Norris et al., 1998] according to the age model (Figure 3). This compilation reveals distinct differences in the number and age of black shale beds between the shallower site (1052) and the deeper site (1050). Other important aspects of the stratigraphy highlighted by the comparison between sites include (1) a 2.43 m recovery gap in Hole $1050 \mathrm{C}$ (between core $27 \mathrm{R}$ and the overlying core $26 \mathrm{R}$ ) at about $99.8 \mathrm{Ma},(2)$ a $3.35 \mathrm{~m}$ recovery gap in Hole $1052 \mathrm{E}$ (between core 40R and core 41R) dated at about $99.9 \mathrm{Ma}$, and (3) the presence of a hiatus of about $0.6 \mathrm{Ma}$ (from 100.5 to $99.9 \mathrm{Ma}$ ) spanning the middle part of the R. appenninica zone at Hole $1050 \mathrm{C}$.

[12] Foraminifera from both sites show good to excellent preservation, which is extremely rare for mid-Cretaceous aged sediments and is of critical importance for obtaining reliable stable isotope records. Stable isotopes were measured on single taxon separates from narrow size fractions of surface-dwelling and deep-dwelling planktonic foraminifera and single and multiple taxon samples of epifaunal benthic foraminifera (depending on species abundance). All samples were analyzed by individual reaction using either a VG Prism or GEO 20-20 mass spectrometer in the United Kingdom (University of Cambridge and National Oceanography Centre Southampton, respectively) and a Kiel III carbonate device (ThermoFinnigan DeltaPlus isotope ratio mass spectrometer at the University of Missouri). Results are reported in standard $\delta$ notation relative to the Vienna Peedee belemnite (PDB) standard. External precision is estimated at $<0.03 \%$ and $<0.06 \%$ for $\delta^{13} \mathrm{C}$ and $\delta^{18} \mathrm{O}$ (one standard deviation) on the basis of replicate analyses of NBS19 and internal lab standards (see the auxiliary material). ${ }^{1}$

[13] Population metrics were calculated for the planktonic assemblage of the Rotalipora appenninica zone samples in both holes (Figure 4). From the relative abundance of planktonic taxa in the $>125 \mu \mathrm{m}$ sieve fraction, "SHE" diversity indices were calculated. Simple species diversity or species richness $(\mathrm{S})$ is the number of species within the counted aliquot without normalizing for sample size. Shannon diversity $(\mathrm{H})$ takes into account the proportion of each species within the sample using the information function $\left[\mathrm{H}(\mathrm{S})=\Sigma \mathrm{p}_{i} \ln \mathrm{p}_{i}\right]$, for $i=1$ to the number of species observed where $\mathrm{p}_{i}$ is the proportion of the total sample represented by the $i$ th species [Shannon, 1949]. Equitability (E) is a measure of the evenness of the species distribution within a sample and is defined as $\mathrm{E}=\mathrm{e}^{\mathrm{H}(\mathrm{S})} / \mathrm{S}$ [e.g., Buzas and Hayek, 1998]. Using 0.1 Ma bins estimated from the age model (Figure 3), we tabulated species richness, number of first appearance datums (FADs), and

[10] The biostratigraphic and chronostratigraphic framework used in this study is based on the stratigraphic positions of planktonic foraminifera and nannofossil datums by Petrizzo and Huber [2006] correlated to the geochrono-

${ }^{1}$ Auxiliary materials are available at ftp://ftp.agu.org/apend/pa/ 2007 pa001517. 

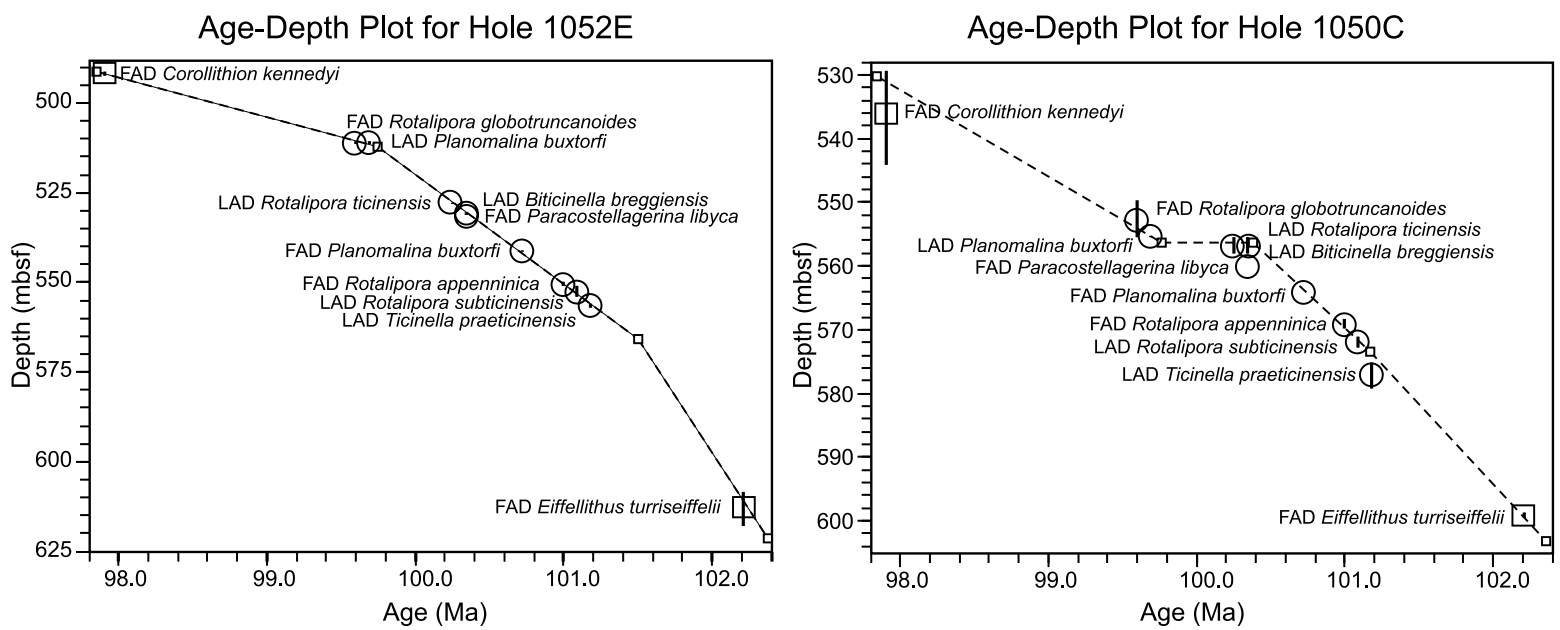

Figure 3. Age-depth curve for sites 1050 and 1052 based on the biostratigraphy of Petrizzo and Huber [2006]. Circles represent planktonic foraminifera, and squares represent calcareous nannofossil species; stratigraphic uncertainty is shown as vertical bars. First appearance datum (FAD); last appearance datum (LAD).

number of last appearance datums (LADs) to calculate speciation and extinction rates through the sections.

\section{Results}

\subsection{SHE Analysis}

[14] Results from simple species diversity (S), Shannon diversity $(\mathrm{H})$, and equitability $(\mathrm{E})$ calculations for the $>125 \mu \mathrm{m}$ sediment sample fractions at sites 1050 and 1052 are presented in Figure 4. At Site 1052, S generally ranges from 15 to 17 species in the lower $R$. appenninica zone $(\sim 100.9-100.4 \mathrm{Ma})$, but it decreases in the middle $R$. appenninica zone $(100.1-100.0 \mathrm{Ma})$ reaching a low of 8 to 11 species at the top of the $R$. appenninica zone (99.6 Ma). S is generally higher at Site 1050, reaching a maximum of 20 species between 100.9 and $100.4 \mathrm{Ma}$ and a minimum of 12 species at about $99.6 \mathrm{Ma}$. H generally parallels $\mathrm{S}$ at both sites. E at Site 1052 generally exceeds that of Site 1050, with relatively high values in the lower $R$. appenninica zone and lower values throughout most of the $R$. appenninica zone. Throughout the upper Albian at both sites, there is no systematic change in any of these metrics associated with elevated TOC values.

[15] Speciation rates at both sites are low in the lower $R$. appenninica zone $(\sim 100.9-100.5 \mathrm{Ma})$ during a time of no species extinctions. The relatively high extinction rate recorded for the $100.5-100.4 \mathrm{Ma}$ bin at Site 1050 (Figure 4) results from an unconformity and coring gap that together span $\sim 0.8 \mathrm{Ma}$; within this same interval at

Table 1. Biostratigraphic Datums Used to Constrain Age-Depth Curves for Sites 1050 and $1052^{\mathrm{a}}$

\begin{tabular}{|c|c|c|c|c|c|c|c|c|}
\hline \multirow[b]{2}{*}{ Datums } & \multicolumn{4}{|c|}{ Hole $1050 \mathrm{C}$} & \multicolumn{4}{|c|}{ Hole $1052 \mathrm{E}$} \\
\hline & $\begin{array}{c}\text { Top } \\
\text { Depth } \\
\text { (mbsf) }\end{array}$ & $\begin{array}{c}\text { Bottom } \\
\text { Depth } \\
\text { (mbsf) }\end{array}$ & $\begin{array}{c}\text { Midpoint } \\
\text { Depth } \\
\text { (mbsf) }\end{array}$ & $\begin{array}{l}\text { Age } \\
\text { (Ma) }\end{array}$ & $\begin{array}{c}\text { Top } \\
\text { Depth } \\
\text { (mbsf) }\end{array}$ & $\begin{array}{c}\text { Bottom } \\
\text { Depth } \\
\text { (mbsf) }\end{array}$ & $\begin{array}{c}\text { Midpoint } \\
\text { Depth } \\
\text { (mbsf) }\end{array}$ & $\begin{array}{l}\text { Age } \\
(\mathrm{Ma}) \\
\end{array}$ \\
\hline FO Corollithion kennedyi & 529.30 & 544.10 & 536.70 & $97.9^{\mathrm{b}}$ & 491.40 & 492.50 & 491.95 & $97.9^{\mathrm{b}}$ \\
\hline FO Rotalipora globotruncanoides & 555.23 & 555.57 & 555.40 & $99.6^{\mathrm{c}}$ & 510.80 & 511.31 & 511.06 & $99.6^{\mathrm{c}}$ \\
\hline LO Planomalina buxtorfi & 555.23 & 555.57 & 555.40 & $99.7^{\mathrm{c}}$ & 510.80 & 511.31 & 511.06 & $99.7^{\mathrm{c}}$ \\
\hline LO Rotalipora ticinensis & 555.57 & 558.10 & 556.84 & $100.3^{\mathrm{c}}$ & 527.93 & 528.13 & 528.03 & $100.3^{\mathrm{c}}$ \\
\hline LO Biticinella breggiensis & 555.57 & 558.10 & 556.84 & $100.4^{\mathrm{c}}$ & 530.87 & 531.32 & 531.10 & $100.4^{\mathrm{c}}$ \\
\hline FO Paracostellagerina libyca & 560.04 & 560.35 & 560.20 & $100.4^{\mathrm{d}}$ & 530.33 & 530.87 & 530.60 & $100.4^{\mathrm{d}}$ \\
\hline FO Planomalina buxtorfi & 564.05 & 564.32 & 564.18 & $100.7^{\mathrm{c}}$ & 541.03 & 541.35 & 541.19 & $100.7^{\mathrm{c}}$ \\
\hline FO Rotalipora appenninica & 568.30 & 569.71 & 569.01 & $100.9^{\mathrm{e}}$ & 549.90 & 551.10 & 550.50 & $100.9^{\mathrm{e}}$ \\
\hline LO Rotalipora subticinensis & 571.20 & 572.78 & 571.99 & $101.1^{\mathrm{c}}$ & 551.10 & 554.10 & 552.60 & $101.1^{\mathrm{c}}$ \\
\hline LO Ticinella praeticinensis & 575.10 & 579.30 & 577.20 & $101.2^{\mathrm{c}}$ & 555.78 & 557.10 & 556.44 & $101.2^{\mathrm{c}}$ \\
\hline FO Eiffellithus turriseiffelii & 598.66 & 599.59 & 599.13 & $102.2^{\mathrm{b}}$ & 608.63 & 618.03 & 613.33 & $102.2^{b}$ \\
\hline
\end{tabular}

${ }^{\mathrm{a}} \mathrm{FO}$, first occurrence; LO, last occurrence. Age according to Gradstein et al. [2004].

${ }^{b}$ Depth from Watkins and Bergen [2003]; Age from Erba et al. [1995].

${ }^{\mathrm{c}}$ Robaszynski and Caron [1995].

${ }^{\mathrm{d}}$ After Leckie et al. [2002].

${ }^{\mathrm{e}}$ Erba et al. [1995]. 

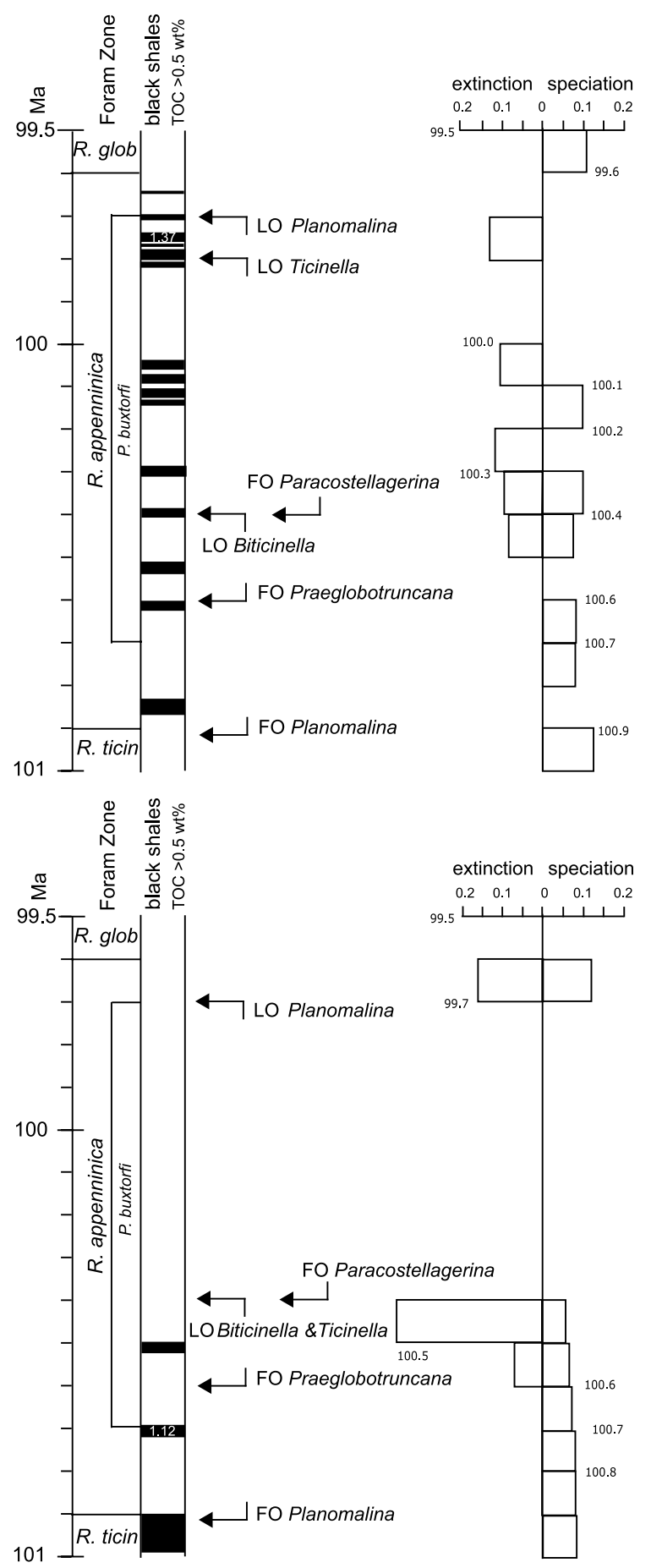

Hole 1052E

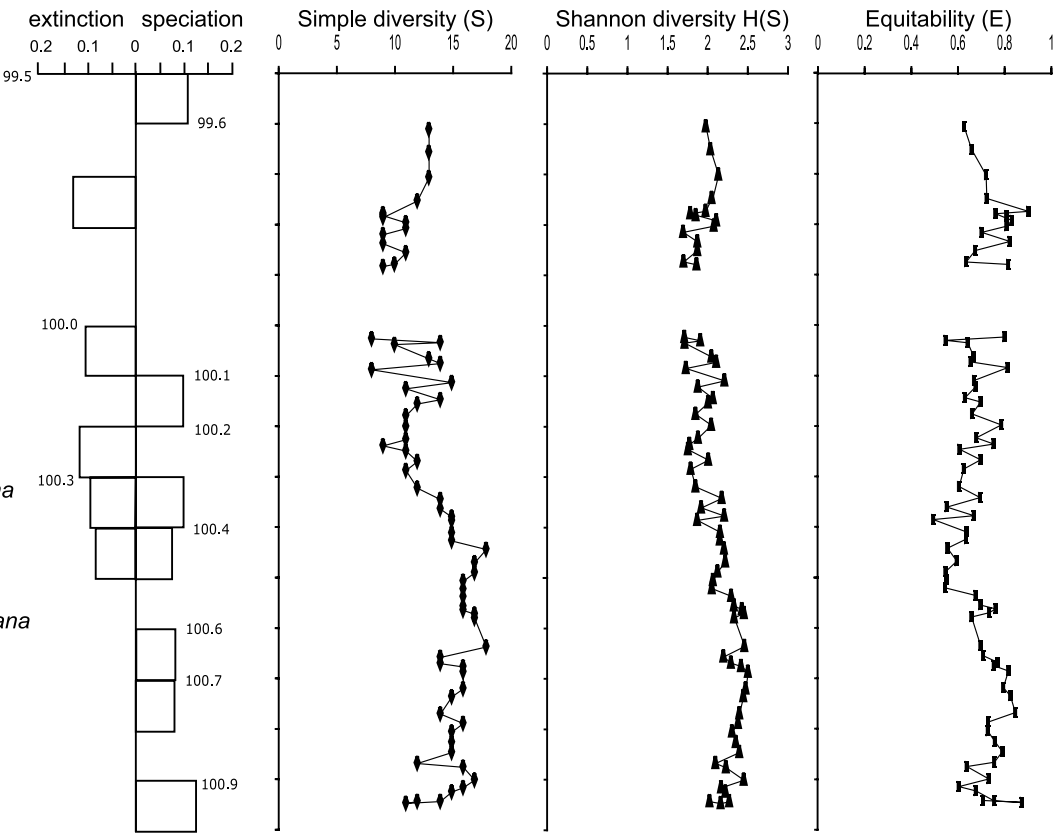

Hole $1050 \mathrm{C}$

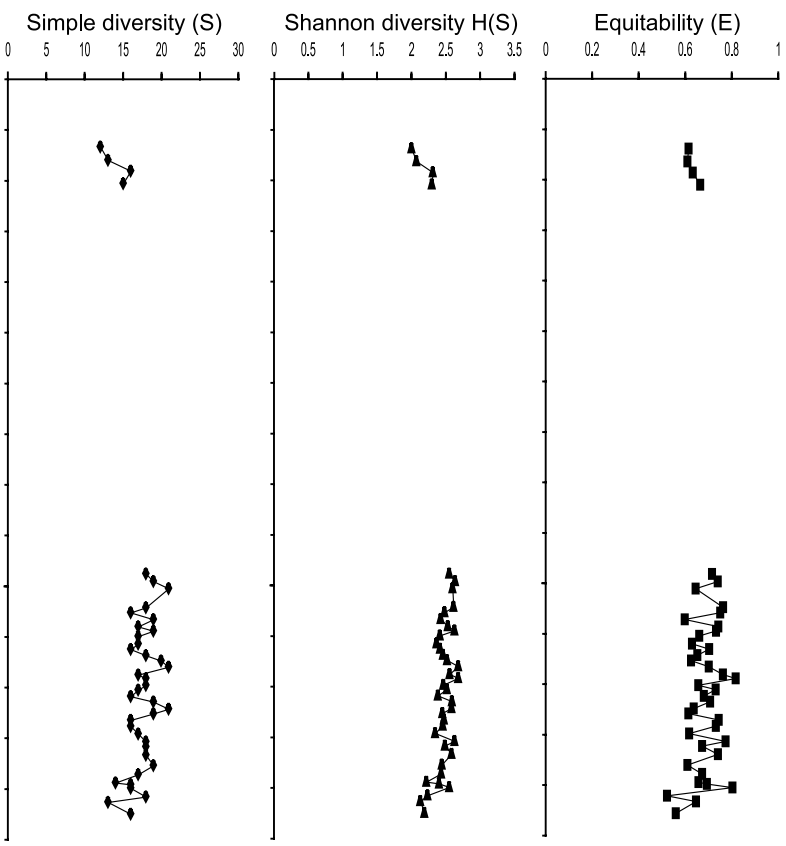

Figure 4. Planktonic foraminiferal diversity indices and evolutionary rates for sites 1050 and 1052 . Evolutionary rates are calculated as follows: rate of speciation equals FADs/S, rate of extinction equals $\mathrm{LADs} / \mathrm{S}$. 


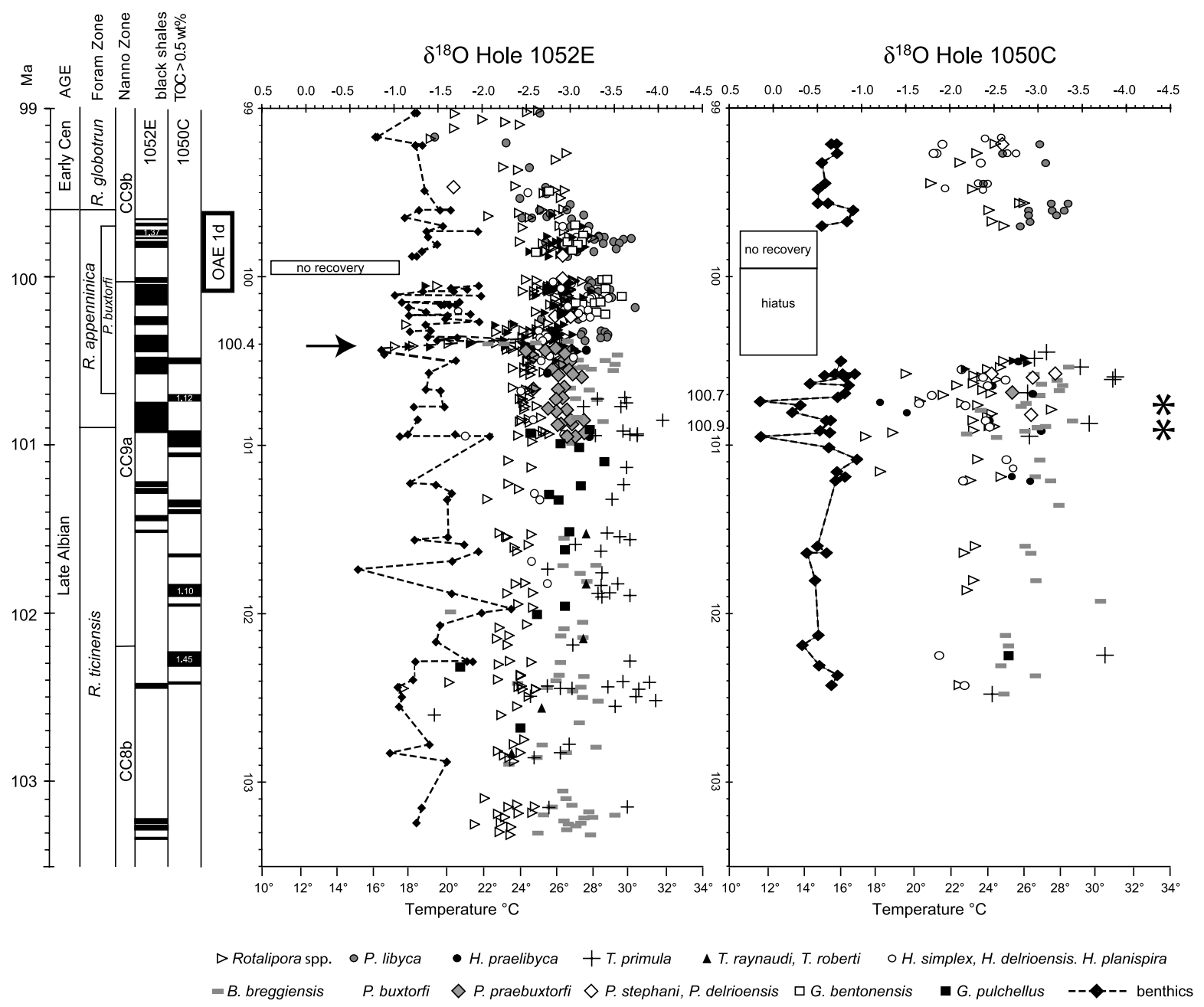

Figure 5a. Oxygen isotope data for sites 1052 and 1050 plotted against age on the basis of the age model of Petrizzo and Huber [2006] using the geochronologic timescale of Gradstein et al. [2004]. Raw data are listed in the auxiliary material. Distribution and thickness of the organic-rich black shales with $>0.5 \% \mathrm{wt} \%$ total organic carbon are from data presented by Norris et al. [1998]. The thickness of the OAE $1 \mathrm{~d}$ interval is based on the carbon isotope stratigraphy discussed in the text. Paleotemperature history is according to the text. Note that arrow indicates interval of reduced planktonic temperature gradient (to $1^{\circ} \mathrm{C}$ ) and increase of bottom water temperature of about $6^{\circ} \mathrm{C}$. Stars indicate intervals of temperature decrease at surface, thermocline, and bottom water depths (to $5^{\circ} \mathrm{C}$ ).

Site 1052, Ticinella primula, T. madecassiana, T. raynaudi, Rotalipora ticinensis, and Biticinella breggiensis become extinct. Speciation and extinction rates are about evenly balanced through the middle and upper $R$. appenninica zone $(\sim 100.5-99.6 \mathrm{Ma})$ at Site 1052 .

\subsection{Oxygen and Carbon Isotopes}

\subsubsection{Site 1050}

[16] Between 102.8 and $99.8 \mathrm{Ma}$, planktonic foraminiferal $\delta^{18} \mathrm{O}$ data from Hole $1050 \mathrm{C}$ show slightly decreasing values $(\sim 0.5 \%$ o $)$ and consistent interspecies offsets (Figure 5a and Data Set S1). Ticinella primula yields the lowest values ranging from -2.87 to $-3.78 \%$ ( $\mu$ mean, -3.28; $\sigma$ standard deviation, 0.47). Biticinella breggiensis,
Paracostellagerina libyca [Georgescu and Huber, 2006], and Globigerinelloides bentonensis consistently yield $\delta^{18} \mathrm{O}$ values that are slightly higher than $T$. primula. Rotalipora and Hedbergella yield the highest values typically ranging between -2.1 and $-2.6 \%$ o $(\mu,-2.26 ; \sigma, 0.41)$, but samples with values approaching benthic values occur within the 101.2-100.6 Ma interval (Figure 5a). Planomalina buxtorfi, $P$. praebuxtorfi, and $G$. pulchellus yield $\delta^{18} \mathrm{O}$ values between the lowest values of Rotalipora and the highest values of $B$. breggiensis.

[17] The $\delta^{18} \mathrm{O}$ values measured from benthic species generally range between -0.92 and $-0.30 \%$ o $(\mu,-0.60$; $\sigma, 0.23)$ and show no long-term trend. Brief $\delta^{18} \mathrm{O}$ shifts to higher values (by $\sim 1.0$ and $0.8 \%$ ) occur at about 101.0 and 


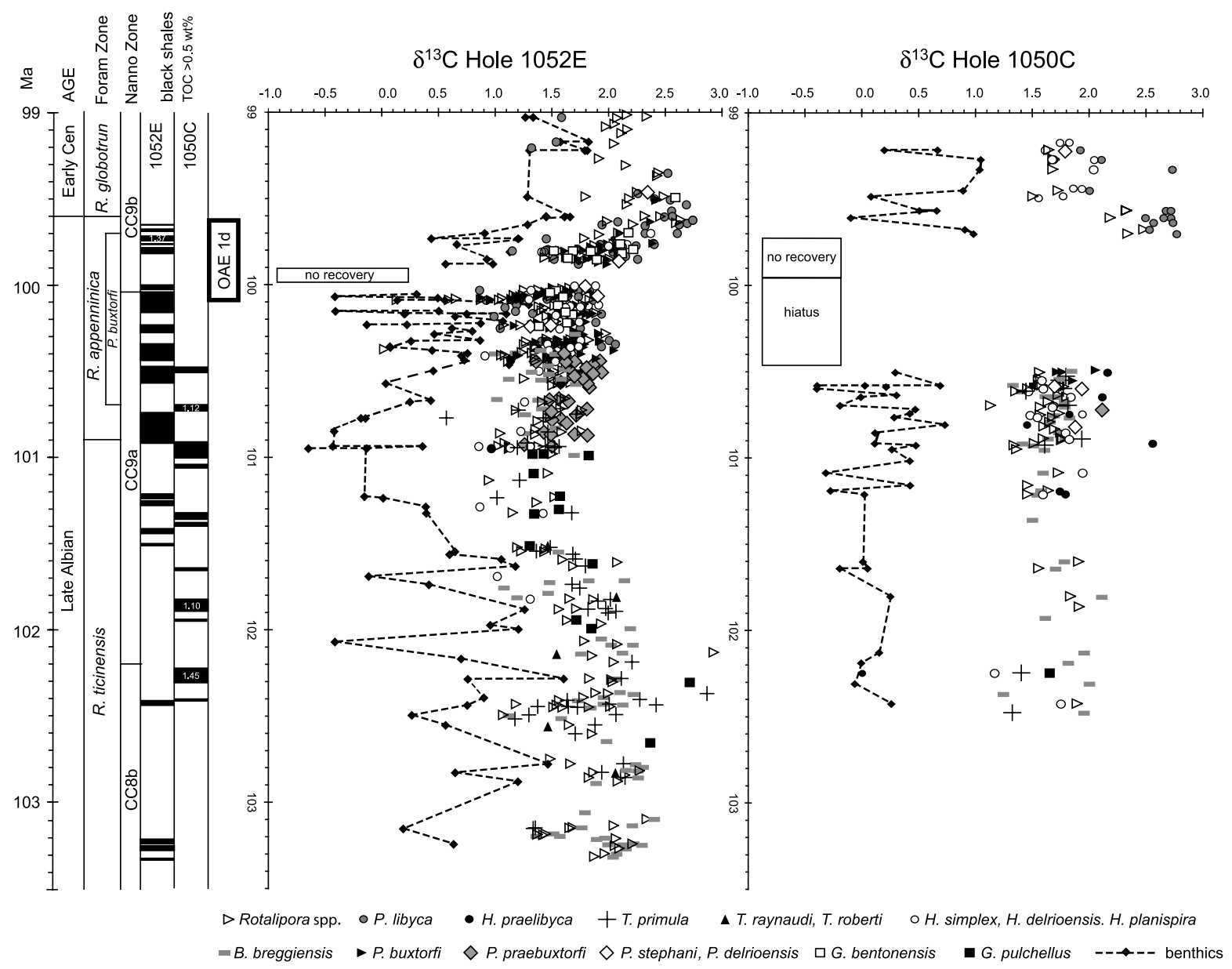

Figure 5b. Carbon isotope data for sites 1052 and 1050 plotted against age on the basis of the age model of Petrizzo and Huber [2006] using the geochronologic timescale of Gradstein et al. [2004]. Raw data are listed in the auxiliary material. Distribution and thickness of the organic-rich black shales with $>0.5 \% \mathrm{wt} \%$ total organic carbon are from data presented by Norris et al. [1998]. The thickness of the OAE $1 \mathrm{~d}$ interval is based on the carbon isotope stratigraphy discussed in the text.

100.8 Ma, respectively. These are accompanied by a 0.5 to $1.0 \%$ shift to higher values among several co-occurring planktonic foraminifera. The benthic $\delta^{18} \mathrm{O}$ values are generally 1.0 to $1.5 \%$ above the highest planktonic values.

[18] There is little, if any, apparent rank ordering in $\delta^{13} \mathrm{C}$ values among planktonic species (Figure $5 \mathrm{~b}$ and the auxiliary material). Within the 102.5-100.5 Ma interval most values range between 1.2 and $2.0 \%(\mu, 1.63 ; \sigma, 0.21)$, with Rotalipora usually yielding slightly lower values than cooccurring B. breggiensis. A positive $\delta^{13} \mathrm{C}$ shift of nearly $1.0 \%$ occurs across the stratigraphic gap that spans the interval from 100.5 to $99.8 \mathrm{Ma}$, with $P$. libyca yielding maximum $\delta^{13} \mathrm{C}$ values of $\sim 2.7 \%$ between 99.7 and 99.6 Ma. The $\delta^{13} \mathrm{C}$ values measured from benthic foraminifera fluctuate between -0.40 and $0.73 \%$ o $(\mu,-0.26 ; \sigma$, $0.39)$. Benthic values may also show a progressive increase across the 100.5 to $99.8 \mathrm{Ma}$ stratigraphic gap; they reach a maximum value of $1.0 \%$ between 99.70 and $99.27 \mathrm{Ma}$.

\subsubsection{Site $\mathbf{1 0 5 2}$}

[19] At Hole 1052E, planktonic foraminifera $\delta^{18} \mathrm{O}$ results are similar to those for Hole $1050 \mathrm{C}$. Values generally range between -2.1 and $-3.8 \%$, and there is a small long-term decrease from 103.3 to 99.8 Ma (Figure 5a and Data Set S2). As with Site 1050, T. primula consistently yields the lowest $\delta^{18} \mathrm{O}$ values, mostly ranging between -3.0 and $-4.0 \%$ o $(\mu$, $-3.37 ; \sigma, 0.50)$. B. breggiensis, $P$. libyca, and $G$. bentonensis yield $\delta^{18} \mathrm{O}$ values that are typically 0.3 to $0.5 \%$ higher than T. primula in the same sample, whereas Rotalipora and Hedbergella consistently yield the highest values, generally ranging between -2.0 and $-3.0 \%(\mu,-2.63 ; \sigma, 0.24)$. P. buxtorfi, P. praebuxtorfi, and G. pulchellus yield $\delta^{18} \mathrm{O}$ values between those of Rotalipora spp. and $B$. breggiensis. The $\delta^{18} \mathrm{O}$ values of Rotalipora and $P$. libyca increase by about $1 \%$ from 99.8 to $99.0 \mathrm{Ma}$.

[20] Benthic $\delta^{18} \mathrm{O}$ values, on the other hand, tend to be lower at Site 1052 than at Site 1050. There is considerable variability among samples with values ranging from -0.85 to $-2.46 \%$ o $(\mu,-1.49 ; \sigma, 0.38)$ between 102.9 and $100.1 \mathrm{Ma}$ and from -1.20 to $-1.98 \%(\mu,-1.38 ; \sigma, 0.29)$ between 100.1 and 99.0 Ma.

[21] Planktonic $\delta^{13} \mathrm{C}$ differences are small but show greater segregation at Site 1052 than at Site 1050 (Figure 5b and the 
auxiliary material). T. primula, P. praebuxtofi, P. buxtorfi, $B$. breggiensis, and $P$. libyca usually yield slightly higher values than Rotalipora spp. and Hedbergella spp., with an average maximum offset of $1 \%$ among these species. Between 103.3 and 101.7 Ma, species with the lower values generally average about $2 \%$ except for a $1.1 \%$ negative shift that occurs between 102.8 and 102.5 Ma. From 101.7 to $101.2 \mathrm{Ma}, \delta^{13} \mathrm{C}$ values decrease to a minimum of $1.2 \%$ and then gradually increase with $P$. libyca yielding the maximum $\delta^{13} \mathrm{C}$ value of $2.7 \%$ at $99.6 \mathrm{Ma}$. Benthic $\delta^{13} \mathrm{C}$ values are variable but generally parallel those of planktonic foraminifera with a typical offset of 0.5 to $1.0 \%$. The lowest values, ranging from -0.1 to $-0.6 \%$ o $(\mu,-0.23 \% ; \sigma, 0.32)$, occur between 101.0 and $100.7 \mathrm{Ma}$, and the highest values of 1.7 to $1.8 \%$ occur between 99.6 and $99.2 \mathrm{Ma}$.

\section{Discussion}

\subsection{Carbon Isotope Patterns}

[22] Carbon isotope values measured from benthic species throughout the studied time interval at both sites generally parallel the planktonic $\delta^{13} \mathrm{C}$ record (Figure $5 \mathrm{~b}$ ). The vertical $\delta^{13} \mathrm{C}$ gradient at Site 1052 averages about $1.4 \%$, whereas at Site 1050 the vertical gradient is greater, averaging about $1.9 \%$. This smaller vertical $\delta^{13} \mathrm{C}$ gradient at Site 1052 results from the generally higher benthic $\delta^{13} \mathrm{C}$ values and reflects the shallower depth of the site. At Site 1052 the lowest $\delta^{13} \mathrm{C}$ values in both benthic and planktonic foraminifera occur between 101.7 and 101.1 Ma. Values increase slightly up to $\sim 100.4 \mathrm{Ma}$ and then return to low values between $\sim 100.2$ and 100.0 Ma. After $\sim 100 \mathrm{Ma}, \delta^{13} \mathrm{C}$ values progressively increase to peak values close to the Albian-Cenomanian boundary just above the extinction level of P. buxtorfi (99.7 Ma) and at the end of black shale deposition, as was described by Wilson and Norris [2001]. At Site 1050 the end of this positive $\delta^{13} \mathrm{C}$ shift is recorded in specimens of $P$. libyca $\left(\delta^{13} \mathrm{C}\right.$ values of 2.60 to $2.77 \%$ at 99.7 to $99.5 \mathrm{Ma}$ ), but the record of the increase in $\delta^{13} \mathrm{C}$ values toward the Albian-Cenomanian boundary is missing as a result of a hiatus and coring gap.

\subsection{Identification and Correlation of OAE 1d}

[23] To understand what factors may have led to the sedimentologic, faunal, and isotopic patterns that occur locally, regionally, or globally across OAE $1 \mathrm{~d}$, this event must be defined in a consistent way. The term OAE $1 \mathrm{~d}$ was introduced by Erbacher and Thurow [1997] to distinguish black shale occurrences and an associated positive carbon isotope shift within the upper Albian P. buxtorfi subzone of the $R$. appenninica zone from OAE $1 \mathrm{~d}$ black shales that occur within the older Rotalipora subticinensis subzone of the $B$. breggiensis zone. OAE $1 \mathrm{~d}$ has subsequently been proposed to occur in at least three other localities (Vocontian Basin [Gale et al., 1996], Site 547 [Nederbragt et al., 2001], and Blake Nose [Wilson and Norris, 2001]) but with different criteria for identifying its onset and termination in different studies.

[24] In the Vocontian Basin, black shales that have been associated with OAE 1d were named Niveau Breistroffer by Bréhéret [1988]. According to Gale et al. [1996] the Niveau Breistroffer from the Mount Risou section in the Vocontian
Basin occurs at the base of calcareous nannofossil subzone $\mathrm{CC} 9 \mathrm{~b}$ and $17 \mathrm{~m}$ below the last appearance datum (LAD) of P. buxtorfi. The Niveau Breistroffer is composed of five relatively organic-rich, dark, laminated marl beds up to $0.7 \mathrm{~m}$ thick alternating with dark gray bioturbated marl across a $10 \mathrm{~m}$ interval. Gale et al. [1996] recorded a $0.5 \%$ positive $\delta^{13} \mathrm{C}$ shift (from 1.5 to $2.0 \%$ ) through the Breistroffer followed by values that fluctuate and then increase by $0.3 \%$ to a peak value of $2.3 \%$ about $14 \mathrm{~m}$ above the last occurrence of $P$. buxtorfi and $22 \mathrm{~m}$ above the top of the Breistroffer (Figure 6).

[25] In a more detailed study of the upper Albian of the Vocontian Basin, Bornemann et al. [2005] distinguished a $6.28 \mathrm{~m}$ thick "main Niveau Breistroffer" that includes four of the five black shale beds distinguished by Gale et al. [1996] and falls entirely within the range of P. buxtorfi (Figure 6). The bulk carbonate stable isotope record produced by Bornemann et al. [2005] shows strongly fluctuating $\delta^{13} \mathrm{C}$ values of 1.0 to $1.5 \%$ o through the main Niveau Breistroffer with the higher values associated with black shale intervals containing up to $2.5 \mathrm{wt} \%$ TOC. A relatively continuous $1.3 \%$ positive $\delta^{13} \mathrm{C}$ shift begins at the top of the main Breistroffer and reaches a maximum of $2.4 \%$ about $5 \mathrm{~m}$ above the main Niveau Breistroffer and $12 \mathrm{~m}$ below the disappearance of P. buxtorfi (Figure 6).

[26] The Niveau Breistroffer has also been recorded in a marginal setting of the Vocontian Basin (Blieux section in SE France, Alpes de Haute Provence). In this proximal area the typical laminated black shales observed in the central part of the Vocontian Basin are absent, and the Niveau Breistroffer is represented by argillaceous marls and marls containing up to $1.0 \mathrm{wt} \%$ TOC [Giraud et al., 2003].

[27] At DSDP Site 547 on Mazagan Plateau (eastern Atlantic), Nederbragt et al. [2001] associated OAE 1d with a long-term $1.5 \%$ positive $\delta^{13} \mathrm{C}$ shift in bulk carbonate that extends from just below the first occurrence (FO) of P. buxtorfi to just above the Albian-Cenomanian boundary (as defined by the first occurrence of $R$. globotruncanoides). The lower portion of the interval associated with OAE 1d interval at Site 547 is characterized by fluctuating positive and negative $\delta^{13} \mathrm{C}$ values, whereas the upper part of this interval shows a nearly continuous positive trend (Figure 6). The upper Albian sequence at Site 547 is dominated by dark marl and mudstone with TOC content ranging between 0.5 and $1.0 \mathrm{wt} \%$, but there are no intervals bearing sediment laminations [Deroo et al., 1984].

[28] At Site 1052, Wilson and Norris [2001] placed the onset of OAE $1 \mathrm{~d}$ on the basis of the initiation of major black shale occurrence within the $R$. appenninica zone using the biostratigraphy of Bellier et al. [2000] and concluded, in light of their new geochemical records, that it should be defined globally on the basis of $\delta^{13} \mathrm{C}$ stratigraphy. The termination of OAE $1 \mathrm{~d}$ was placed at the level of maximum $\delta^{13} \mathrm{C}$ values near the Albian-Cenomanian boundary, which correlates well with the peak $\delta^{13} \mathrm{C}$ values [Gale et al., 1996] in the Vocontian Basin and at DSDP Site 547 [Nederbragt et al., 2001]. Using a neutron porosity downhole log, Wilson and Norris [2001] developed an orbital cyclostratigraphybased age model for the upper Albian interval at Site 1052 and calculated that the interval between the FO of 

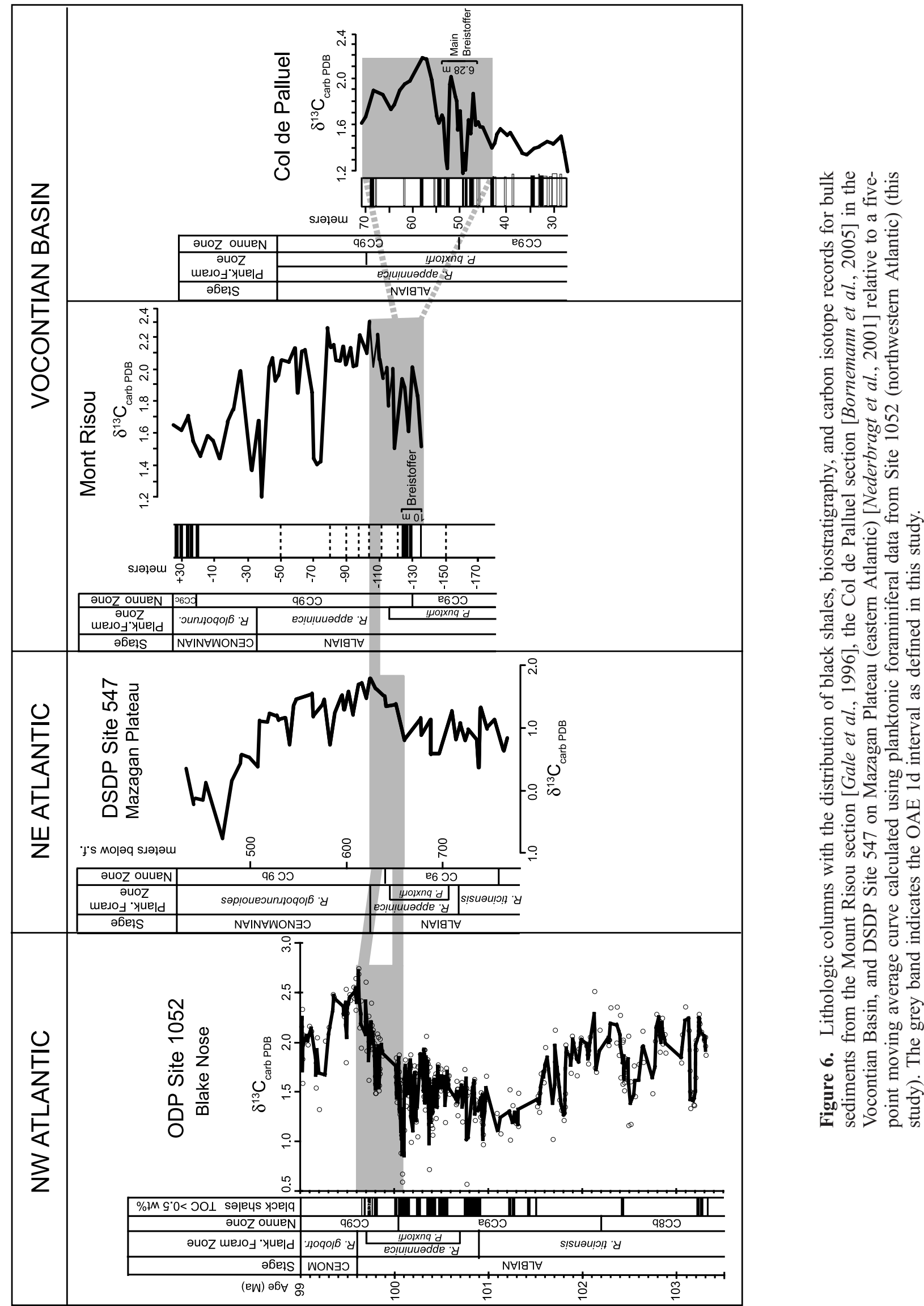
R. appenninica and the FO of the calcareous nannofossil Eiffelithus turriseiffelii represents $\sim 1.3 \mathrm{Ma}$. On this basis, they concluded that the OAE $1 \mathrm{~d}$ interval has a duration of about $280 \mathrm{ka}$. In contrast, Petrizzo and Huber [2006] determined that the OAE 1d interval as defined by Wilson and Norris [2001] lasted about $500 \mathrm{ka}$ on the basis of a revised biostratigraphy of the site and an age model that is constrained by calcareous nannofossil and planktonic foraminiferal datums.

[29] Comparison of the North Atlantic and Vocontian Basin $\delta{ }^{13} \mathrm{C}$ records demonstrates that $\delta^{13} \mathrm{C}$ correlation of the interval assigned to OAE $1 \mathrm{~d}$ is somewhat equivocal, particularly because of the strong fluctuations in the earlier phase (Figure 6). One approach would be to define OAE 1d as the interval from the lowest planktonic and benthic $\delta^{13} \mathrm{C}$ values near the top of the $R$. ticinensis zone $(\sim 101.1 \mathrm{Ma})$ to the highest values just across the Albian-Cenomanian boundary ( $\sim 99.6 \mathrm{Ma})$. This $2 \%$ o shift across $\sim 1.4 \mathrm{Ma}$ includes an early phase of fluctuating $\delta^{13} \mathrm{C}$ values (from 101.1 to $100.1 \mathrm{Ma}$ ) and a later phase of more continuously increasing $\delta^{13} \mathrm{C}$ values (from 100.1 to $99.6 \mathrm{Ma}$ ). To avoid ambiguity in correlating the onset of OAE $1 \mathrm{~d}$, we restrict OAE $1 \mathrm{~d}$ to the later phase showing the more continuous $1.2 \% \delta^{13} \mathrm{C}$ increase (Figure 6).

[30] The $\delta^{13} \mathrm{C}$ stratigraphy and the lower and upper tie points that we have used to identify the OAE $1 \mathrm{~d}$ interval at the Blake Nose sites closely correlate with the record obtained in the upper Albian sequence at Site 547 on Mazagan Plateau. Moreover, the upper part of the longterm $\delta^{13} \mathrm{C}$ enrichment observed at sites 1052 and 547 can be correlated with the $0.5 \%$ positive $\delta^{13} \mathrm{C}$ shift recorded in upper Albian bulk carbonate sediments from the Mount Risou section in the Vocontian Basin [Gale et al., 1996], but the positive carbon isotope shift at $\mathrm{Col}$ de Palluel section reported by Bornemann et al. [2005] is considered to occur within the positive $\delta^{13} \mathrm{C}$ shift that identifies the OAE $1 \mathrm{~d}$ (Figure 6). This chemostratigraphic definition seems to allow consistent recognition of an OAE $1 \mathrm{~d}$ interval but emphasizes that the most positive $\delta^{13} \mathrm{C}$ values are not associated with the deposition of black shales at any locality investigated to date.

\subsection{Planktonic Foraminiferal Depth Ecology}

[31] Depth habitats of planktonic foraminifera can be estimated by comparing interspecies differences in carbon and oxygen isotope values among taxa from the same sample (Figure 7). Because the $\delta^{18} \mathrm{O}$ of calcite precipitated in equilibrium with ambient seawater is temperaturedependent and temperature decreases with depth from the ocean surface to the seafloor, modern deeper-dwelling planktonic foraminifera have higher $\delta^{18} \mathrm{O}$ values than surface-dwelling taxa [e.g., Emiliani, 1954; Shackleton and Vincent, 1978; Fairbanks et al., 1980, 1982]. For carbon, preferential fixing of ${ }^{12} \mathrm{C}$ during photosynthesis in the euphotic zone and remineralization of this isotopically light carbon at depth result in decreasing $\delta^{13} \mathrm{C}$ values from the surface mixed layer to the seafloor. Thus consistent $\delta^{18} \mathrm{O}$ and $\delta^{13} \mathrm{C}$ offsets among fossil taxa assemblage can be used to infer relative depth habitats.
[32] Problems associated with using stable isotopes to estimate the ecology of planktonic foraminifera have been reviewed by several authors [Wefer and Berger, 1991; D'Hondt and Arthur, 1995; Spero et al., 1997; Zeebe, 1999]. In addition to depth, differences in $\delta^{18} \mathrm{O}$ and $\delta^{13} \mathrm{C}$ among samples may be influenced by (1) kinetic effects if calcification rates vary among specimens, species, or samples or through ontogeny; (2) depth migration though ontogeny; (3) peaks in abundance during different seasons for different taxa; (4) the presence of algal symbionts; (5) measurement error $(\leq 0.1 \%$ ); (6) other environmental factors (e.g., pH, alkalinity); and (7) diagenetic artifacts. There is no evidence of either ontogenetic depth migration or algal symbionts in the taxa analyzed [Norris and Wilson, 1998]. To further minimize ontogenic and perservational artifacts, we analyzed only the best preserved specimens of the most abundant species, and these specimens were taken from a narrow size fraction.

[33] Seasonal variability is a confounding factor if depth is considered the controlling variable in temperature variations, but seasonality can also be exploited as a paleoceanographic signal [e.g., Rohling et al., 2004; Isaza-Londoño et al., 2006]. All 12 modern planktonic foraminifera collected in a classic sediment trap study in the Sargasso Sea occurred in significant numbers during only 2 to 6 months each year and were rare or completely absent during the remaining months [Deuser and Ross, 1989]. Seasonal changes in populations must also have occurred among fossil taxa, and isotopic values will track conditions during the season of growth. Characterizing isotopic variability in multiple single specimens from the same sample provides a way to assess intraannual and interannual variability that can be compared among samples [Isaza-Londoño et al., 2006]. This approach generates data with a temporal resolution (the $\sim 1$ month life span of a planktonic foraminifer) appropriate for investigating changes in seasonality through a section, but it is analytically intensive and impractical unless understanding seasonality is the goal of the study. However, because isotopic variability among specimens can be high, differences between analyses of multiple specimens can include variance associated with interannual differences in temperature [Isaza-Londoño et al., 2006]. Thus the stability-of-signal concepts developed for the Quaternary may be useful in refining paleoecological interpretations [Rohling et al., 2004]. Specifically, the thin summer mixed layer is expected to experience relatively large and frequent short-term perturbations in temperature and salinity not seen in other portions of the planktic realm. This difference should be reflected in more variability in $\delta^{18} \mathrm{O}$ values among samples for taxa that lived in the summer mixed layer than those that lived below the seasonal thermocline or in the thick winter mixed layer.

[34] Applying this model combined with observed differences in average in $\delta^{18} \mathrm{O}$ and $\delta^{13} \mathrm{C}$ values among taxa, T. primula and $P$. libyca are interpreted as summer mixed zone dwellers. They exhibit relatively high variability in $\delta^{18} \mathrm{O}$ and $\delta^{13} \mathrm{C}$ among samples and show the lowest $\delta^{18} \mathrm{O}$ and highest $\delta^{13} \mathrm{C}$ of the taxa analyzed. B. breggiensis also shows relatively high variability among samples but has slightly higher $\delta^{18} \mathrm{O}$ values and slightly lower $\delta^{13} \mathrm{C}$ values 

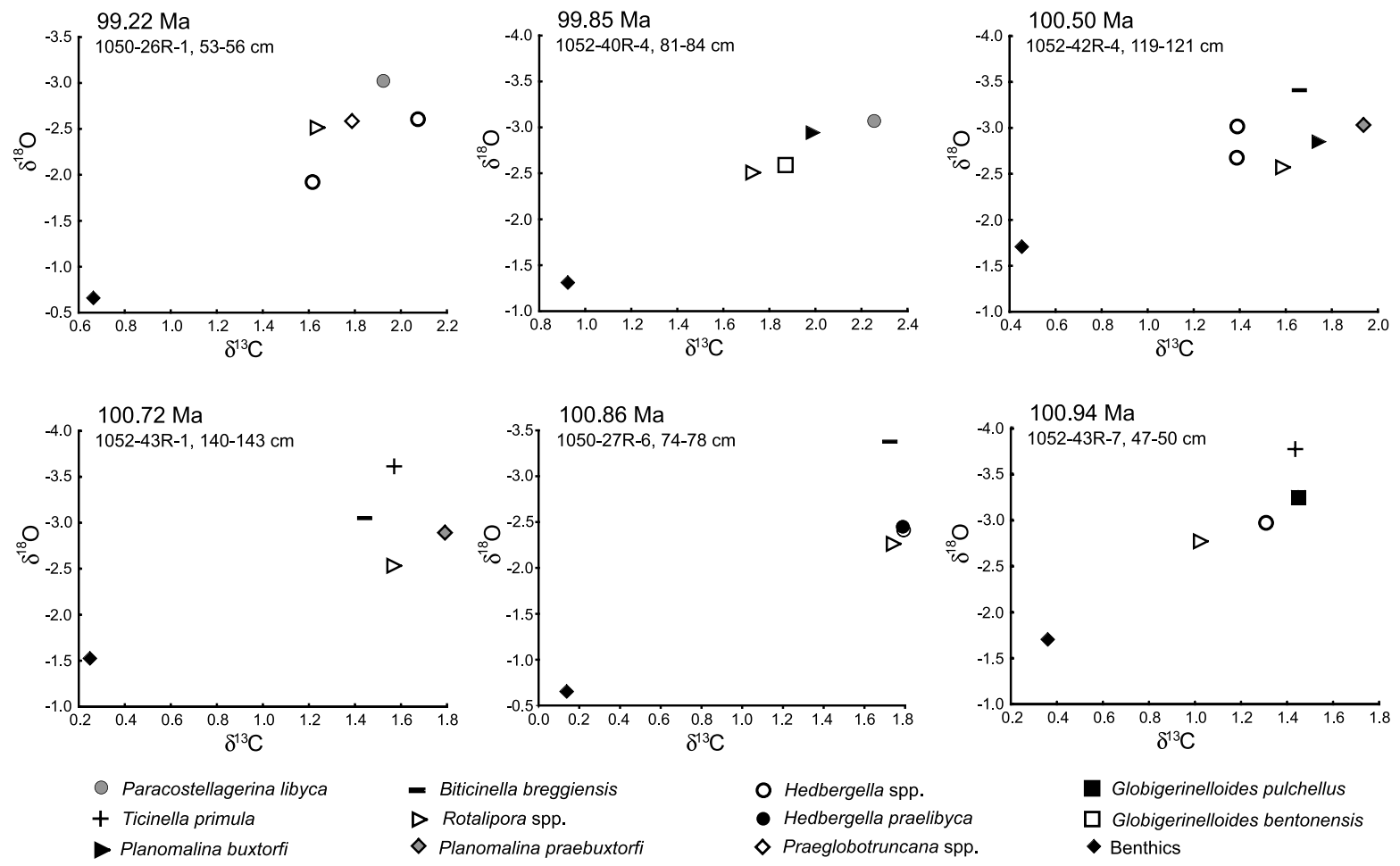
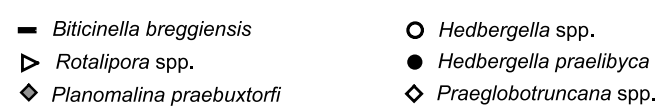

Figure 7. Stable isotope crossplots for select benthic and planktonic foraminifera shown for two samples from Site 1050 and four samples from Site 1052. Inferred depth habitats P. libyca and T. primula are summer mixed layer dwellers; B. breggiensis is a spring mixed layer dweller; Hedbergella spp. and Rotalipora spp. are thermocline dwellers; Globigerinelloides spp., Planomalina spp., and Praeglobotruncana spp. are winter mixed layer dwellers. Raw data are listed in the auxiliary material.

than $T$. primula, suggesting that B. breggiensis lived near the seasonal thermocline and/or slightly earlier or later in the year than T. primula. Rotalipora spp. and Hedbergella simplex yield stable isotope records with relatively little variability between samples but the highest $\delta^{18} \mathrm{O}$ values and usually the lowest $\delta^{13} \mathrm{C}$ values, suggesting that they probably lived below the seasonal thermocline, possibly near the permanent thermocline. Finally, Planomalina, Praeglobotruncana, and Globigerinelloides also have isotopic values with relatively little variation among samples. Their $\delta^{18} \mathrm{O}$ values generally fall between that of inferred summer surface-dwelling and seasonal subthermocline species, and their $\delta^{13} \mathrm{C}$ values are generally slightly higher than the summer subthermocline species. Thus these three taxa are hypothesized to have inhabited the thick winter mixed layer. Like the summer subthermocline waters to which it gives rise, the winter mixed layer is unlikely to experience big changes in temperature and salinity, but it is in contact with the atmosphere and should show little effect of respired ${ }^{12} \mathrm{C}$-rich $\mathrm{CO}_{2}$.

\subsection{Paleotemperature History}

[35] Oxygen isotope values measured on different planktonic and benthic taxa at both sites provide a detailed record of changes in paleotemperatures through the water column and along a depth transect. To calculate paleotemperatures, we used the equation of Bemis et al. [1998] and assume a value of $-1.0 \%$ standard mean ocean water (SMOW) for the mean isotopic composition of seawater in a nonglacial world [Shackleton and Kennett, 1975], which corresponds to a value of $-1.27 \%$ in the temperature equation [Hut, 1987]. On the assumption that adjusting calculations of sea surface temperature to modern sea surface latitudinal $\delta^{18} \mathrm{O}$ gradients is better practice than using the mean, ice-free seawater $\delta^{18} \mathrm{O}$ value, the seawater value used for temperature estimates from planktonic taxa was reduced by $0.75 \%$, a value appropriate for a paleolatitude of $25^{\circ} \mathrm{N}$ [Zachos et al., 1994; Ogg and Bardot, 2001].

[36] In the R. ticinensis zone at both sites, $\delta^{18} \mathrm{O}$ measurements for benthic, summer mixed, and subthermoclinedwelling species are well separated, suggesting relatively strong water column stratification. In general, estimated summer mixed zone temperatures range from $26^{\circ} \mathrm{C}$ to $31^{\circ} \mathrm{C}$, whereas waters below the seasonal thermocline range from $22^{\circ} \mathrm{C}$ to $26^{\circ} \mathrm{C}$ at Site 1052 and from $17^{\circ} \mathrm{C}$ to $25^{\circ} \mathrm{C}$ at Site 1050. Average benthic $\delta^{18} \mathrm{O}$ values at Site 1052 (range -0.85 to $\left.-2.46 \% ; \mu,-1.46 \% ; \sigma, 0.36 \% ; \sim 19^{\circ} \mathrm{C}\right)$ are lower than at Site 1050 (range -0.30 to $-0.92 \%$; $\mu$, $-0.60 \% ; \sigma, 0.23 \% ; \sim 15^{\circ} \mathrm{C}$ ), suggesting that bottom waters at the shallower site were about $4^{\circ} \mathrm{C}$ warmer than at the deeper site (Figure 5a). The vertical temperature gradient ranges from $11^{\circ} \mathrm{C}$ to $15^{\circ} \mathrm{C}$ at Site 1050 , whereas it is smaller at Site 1052 (from $7^{\circ} \mathrm{C}$ to $11^{\circ} \mathrm{C}$ ). 
[37] A perturbation in the water column stratification is observed at the base of the $R$. appenninica zone at Site 1050 where an increase in $\delta^{18} \mathrm{O}$ values of the subthermocline dwellers Hedbergella spp. and Rotalipora spp. and of the subsurface mixed layer dweller B. breggiensis at about 100.9 and $100.7 \mathrm{Ma}$ suggests a cooling of about $5^{\circ} \mathrm{C}$ at the surface and thermocline depths. These changes are accompanied by a similar decrease in the bottom water temperature as indicated by $1.0 \%$ positive shift in benthics $\delta^{18} \mathrm{O}$ values (Figure 5a). These episodes are followed by a decrease in the epipelagic to thermocline planktonic temperature gradient (to $\sim 2^{\circ} \mathrm{C}$ ) at about $100.5 \mathrm{Ma}$ as indicated by the similar $\delta^{18} \mathrm{O}$ values of the mixed layer dweller T. primula and the subthermocline dweller Rotalipora spp. (Figure 5a). At Site 1052 the $\delta^{18} \mathrm{O}$ values measured in the $R$. appenninica zone of Rotalipora spp. suggest an increase of about $2^{\circ} \mathrm{C}$ at thermocline depths, but there is no correlative surface warming indicated in the $\delta^{18} \mathrm{O}$ values of $T$. primula and $P$. libyca resulting in lower inferred planktonic temperature gradients. A decrease in estimated planktonic temperature gradients (to $\sim 3^{\circ} \mathrm{C}$ ) occurs in the middle part of the range of $P$. buxtorfi, and at $100.4 \mathrm{Ma}$ the vertical temperature gradient is close to only $1{ }^{\circ} \mathrm{C}$ (Figure 5a). In addition, at Site 1052 benthic $\delta^{18} \mathrm{O}$ values exhibit an increase in bottom water temperature of $2^{\circ} \mathrm{C}$ from the appearance level of $P$. buxtorfi to the middle of its stratigraphic range (i.e., from $\sim 100.7$ to $\sim 100.1 \mathrm{Ma}$ ), and a marked increase of about $6^{\circ} \mathrm{C}$ (benthic $\delta^{18} \mathrm{O}$ values converge on planktonic values) occurs at $100.4 \mathrm{Ma}$, suggesting that bottom water warmed to $\sim 22^{\circ} \mathrm{C}$ at this time. Unfortunately, a hiatus is present at the correlative levels in Hole $1050 \mathrm{C}$ precluding tests for any paleotemperature similarities or differences between sites (Figure 5a).

[38] Above the extinction level of P. buxtorfi at Site 1052 an interval of overlap between the $\delta^{18} \mathrm{O}$ values of the surface-dwelling $P$. libyca and the subthermocline-dwelling species of Rotalipora and Hedbergella is associated with a progressive decrease of $\delta^{18} \mathrm{O}$ values (Figure 5a). Such a decrease in $\delta^{18} \mathrm{O}$ values is also observed at Site 1050, although the overlap between $P$. libyca and species of Rotalipora and Hedbergella is smaller at this site. The overall trend at both sites suggests $3^{\circ} \mathrm{C}$ to $5^{\circ} \mathrm{C}$ of surface water cooling from 99.7 to $99.0 \mathrm{Ma}$.

\subsection{Inferences on Planktonic Foraminiferal Evolution and Paleoceanographic Changes}

[39] Variations in the discussed temperature records correspond to changes in vertical stratification of the water column and may reflect switches from oligotrophic to mesotrophic conditions. Comparison of isotopic records with planktonic foraminiferal species diversity, equitability, and evenness (SHE diversity indices) as well as speciation and extinction rates provides independent evidence regarding the availability of niche space and possible ecological stresses through time. Greater stratification would be expected to increase the availability of niche space favoring speciation and/or immigration. Consistent with this scenario, diversity indices are relatively high in the $R$. ticinensis zone and at the base of the $R$. appenninica zone (Shannon values $>2$ and equitability close to 1; Figure 4), which we interpret to represent relatively oligotrophic conditions.

[40] Appearances at 100.9 Ma of both R. appenninica and the short-lived genus Planomalina and at 100.6 Ma of Praeglobotruncana at the shallower Site 1052 coincide with an interval of increasing temperature of about $2^{\circ} \mathrm{C}$ at the base of the thermocline with respect to the inferred temperature in the underlying $R$. ticinensis zone. A modest shoaling or reduction of the thermocline depth may explain this change (Figure 8). During the same time interval the oxygen isotope records at the deeper Site 1050 indicate a decrease in surface, thermocline, and bottom water temperatures at about both 100.9 and $100.7 \mathrm{Ma}$ that may reflect short episodes of cooling of the entire water column.

[41] Such a difference in water mass stratification between two closely spaced sites points to a response to local surface water circulation. Considering the late Albian paleogeography, the location of sites 1052 and 1050, and their inferred paleodepths $(\sim 500 \mathrm{~m}$ at Site 1052 and $\sim 1500 \mathrm{~m}$ at Site $1050)$, it is likely that a wind-driven surface water circulation similar to the modern western boundary current of the North Atlantic Gyre was active at that time [Wilson and Norris, 2001] and hence may have influenced the vertical stratification of the water column over Blake Plateau (Figure 9). The hypothesis that a proto-Gulf Stream was actively flowing during the late Maastrichtian across the Blake Plateau has been demonstrated on the basis of studies of calcareous nannofossil assemblages that indicate the occurrences of a strong thermal contrast between onshore and offshore surface water masses over this area [Watkins and Self-Trail, 2005]. We infer that an incipient and, most likely, sporadic protowestern boundary current was already present during the late Albian (Figure 9) in agreement with the general circulation models (GCMs) [e.g., Barron and Peterson, 1990; Poulsen et al., 1999].

[42] Studies of the modern Gulf Stream system demonstrate that the size and velocity of this western boundary current are highly variable seasonally and on longer timescales. It is a complex system that flows northeastward over the continental shelf of the North American Atlantic coast, it plays an important role in the poleward transfer of heat, and it shows a high degree of mesoscale activities. It separates cold slope water of the continental shelf to the west from warm oceanic water to the east, creating a prominent temperature contrast (Figure 9). Isotopic values measured on living planktonic foraminifera show distinctive signals revealing that the modern boundary current displays seasonal fluctuations in the strength of vertical stratification [Fairbanks et al., 1980].

[43] We suggest that the differences in stratification between sites at 100.9-100.7 Ma observed at Blake Nose can be explained in terms of variability in a proto-North Atlantic Gulf Stream system. Shoaling of the thermocline at the shallower Site 1052 for this time is consistent with an increase in protowestern boundary current strength that shoaled the thermocline, bringing cooler, more nutrient-rich water onto the slope. The cooling signals recorded in the bottom and surface water records at Site 1050 are consistent with this interpretation. 


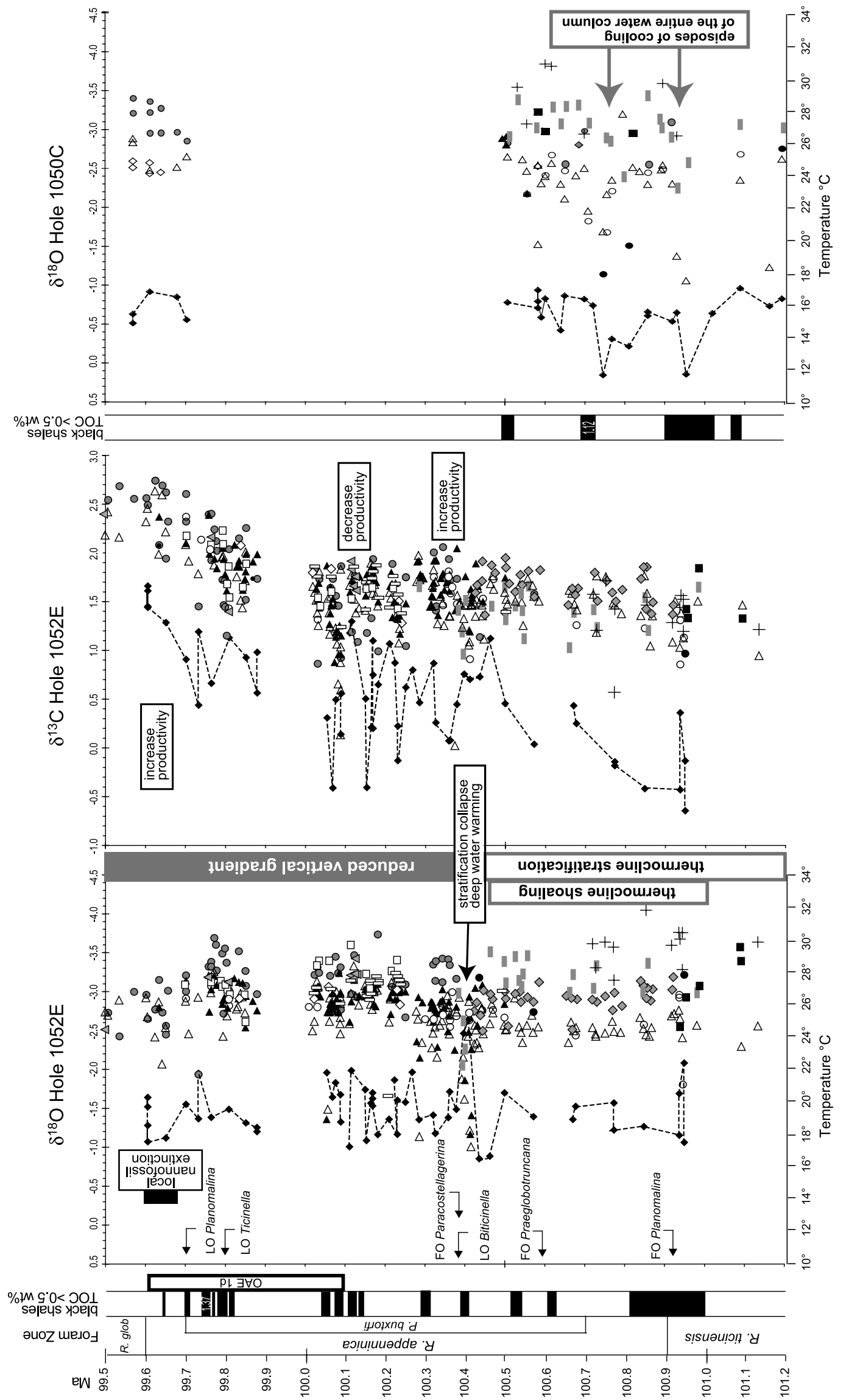

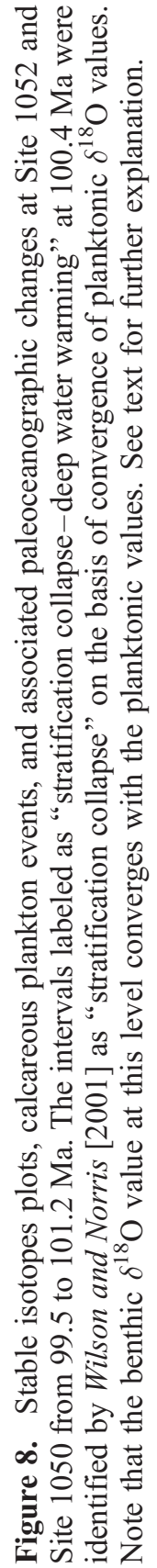



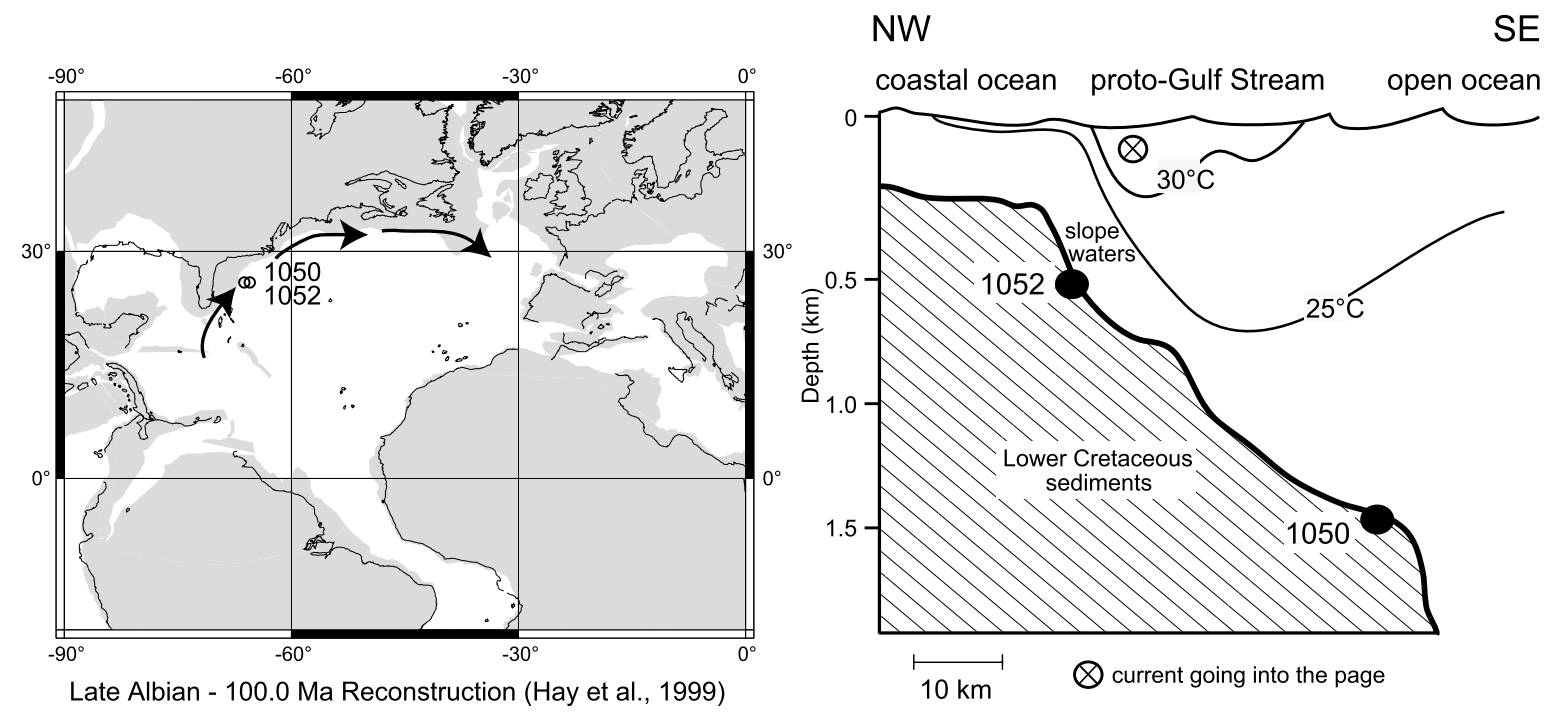

Figure 9. Model of a depth transect across a proto-Gulf Stream over the Blake Nose studied sites. The $30^{\circ} \mathrm{C}$ and the $25^{\circ} \mathrm{C}$ isotherms are showed separating the warm surface current and the slope waters. Migrations of a protowestern boundary current along the continental margin cause the shoaling of the thermocline at Site 1052 and bring cold water onto the slope at Site 1050 (100.9-100.7 Ma). At 100.4 Ma an increase of the protowestern boundary current over Site 1052 results in a global warming throughout the entire water column. See text for further explanations.

[44] The faunal turnover observed within the P. buxtorfi subzone (100.7 to $99.7 \mathrm{Ma}$ ) includes the extinction of two long-ranging lineages (Biticinella and Ticinella) and the appearance of new species groups (Praeglobotruncana and Paracostellagerina). According to the $\delta^{18} \mathrm{O}$ values the appearance of P. libyca and the extinction of Biticinella at about $100.4 \mathrm{Ma}$, and later the extinction of Ticinella (99.8 Ma), occurred during a phase of reduced planktonic temperature gradients $\left(<3^{\circ} \mathrm{C}\right)$ and presumably relatively weak stratification (Figure 8). Simple diversity and the Shannon value show decreased values at this time (Figure 4), which could indicate a shift to less stable, more mesotrophic conditions. Convergence of the $\delta^{18} \mathrm{O}$ records of the mixed-layer-dwelling (B. breggiensis, $P$. buxtorfi) and the subthermocline-dwelling species (Rotalipora spp.) and the convergence of the benthic $\delta^{18} \mathrm{O}$ values on planktonic values at 100.4 Ma suggest enhanced vertical mixing and bottom water warming at this time. On the basis of data for planktonics alone, convergence of the planktonic $\delta^{18} \mathrm{O}$ records at $100.4 \mathrm{Ma}$ was interpreted by Wilson and Norris [2001] as evidence of a collapse in upper surface water stratification. We hypothesize that this collapse and warming of the bottom water resulted from strengthening and broadening of the protowestern boundary current until its westward limit crossed over Site 1052, resulting in a warming throughout the entire water column and a pronounced vertical mixing (Figure 9). This episode is immediately followed (at about $100.38 \mathrm{Ma}$ ) by an increase of surface $\delta^{13} \mathrm{C}$ values (up to 2.05\%) for the subsurface dwellers (Planomalina spp.) and surface dwellers (P. libyca), which may reflect increased productivity in the upper mixed layer (Figure 8). This interpretation of increased surface water productivity at this time is consistent with changes in calcareous nannofossil populations recorded at Site 1052 by Watkins et al. [2005]. According to Watkins et al. a progressive increase in the maximum abundance of the mesotrophic taxa and a concomitant decrease in the oligotrophic taxa occurred across the interval of reduced vertical gradient. Within the planktonic foraminiferal population this perturbation in the mixed layer may have favored the appearance of more mesotrophic taxa, such as the surface dweller Paracostellagerina, and perhaps led to the extinction of the more specialized Biticinella at 100.38 Ma.

[45] A second perturbation in the stable isotope records is observed at about 100.1-100.2 Ma where planktonic foraminifera record the lowest simple diversity values (Figure 4), the benthic $\delta^{13} \mathrm{C}$ values converge on the planktonic values, and $P$. libyca yields the lowest $\delta^{13} \mathrm{C}$ values among the planktonics. No appearances or extinctions in the planktonic foraminiferal record are observed within this time slice, which we interpret to represent a short phase of decreased surface water productivity. Both of these episodes of increasing and decreasing of surface water productivity may have been related to fluctuations in the strength of vertical stratification of the proto-Gulf Stream.

[46] The Planomalina extinction at $99.7 \mathrm{Ma}$, which falls close to the large positive $(\sim 2 \%$ ) carbon isotope excursion in planktonic and benthic foraminifera, is correlated with the simultaneous extinction of 13 nannofossil species that were endemic to the Blake Nose area and had evolved during the period of increased stratification in the earlier part of the P. buxtorfi range. This extinction also correlates with a phase of surface mixing and peak productivity in the 
surface waters, as indicated by the high nannofossils nutrient index registered by Watkins et al. [2005]. Thus comparison between extinction and speciation rates and the stable isotope record reveal that the late Albian faunal turnover affects only surface- and subsurface-dwelling species, with Ticinella and Biticinella being replaced by Praeglobotruncana and Paracostellagerina.

\subsection{Black Shale Formation at Blake Nose}

[47] Opinions have varied regarding the main cause of black shale formation during the mid-Cretaceous (see Herrle et al. [2003] for a review). Both productivity and preservational models have been advanced for Albian black shales. High accumulation rates of organic matter may have resulted from an increase in surface water productivity due to intensified vertical mixing of the water column and an increased nutrient supply [e.g., Arthur et al., 1987; Pedersen and Calvert, 1990; Wilson and Norris, 2001]. Alternatively, increased $\mathrm{C}_{\text {org }}$ accumulation has been attributed to enhanced preservation of organic matter due to oxygen minimum conditions developed in a well-stratified water column [e.g., Bralower and Thierstein, 1984; Nederbragt et al., 2001].

[48] Bornemann et al. [2005] suggested that formation of late Albian black shales in the Vocontian Basin resulted from enhanced preservation. They surmised that greater monsoonal activity led to increasing humidity and wind stress causing a decrease in low latitude deep water formation and an increase in surface water stratification.

[49] Either of these organic carbon accumulation mechanisms results in burial of ${ }^{12} \mathrm{C}$-rich organic carbon and increased $\delta^{13} \mathrm{C}$ values in the ocean reservoir, which is then recorded in the global sedimentary record. At Blake Nose, Wilson and Norris [2001] postulated that the decrease in planktonic $\delta^{18} \mathrm{O}$ gradients during OAE $1 \mathrm{~d}$ reflected a collapse in the vertical thermal gradient during a period of increased wind-driven deep winter mixing and reduced summer stratification that fostered higher productivity. This scenario is very different from the "megasapropel" model of Erbacher et al. [2001] for the earlier OAE 1b indicating that even at the same locality, similar depositional patterns could result from essentially opposite hydrographic forcing.

[50] Determining the cause(s) of OAE 1d is not simple and is complicated by the fact that organic-rich deposits are not tightly correlated with the $\delta^{13} \mathrm{C}$ excursion at any of the localities studied to date. Until the site(s) of organic carbon burial is (are) found, it will be difficult to connect local paleontological and paleoceanographic observations to regional to global shifts in the proportion of carbon buried as organic matter.

[51] Still, the Blake Nose record does provide constraints on the controls on local depositional patterns. The onset of black shale formation is not accompanied by a consistent ocean temperature change. Beds yielding $>0.5 \mathrm{wt} \%$ TOC are associated with intervals of general cooling of the water column at Site 1050 (i.e., at $100.9 \mathrm{Ma}$ ), as well as with intervals of warming of the deep water and stratification collapse of the entire water column at Site 1052 (i.e., at 100.4 Ma). Additional observations include the following:

[52] 1. Black shale deposition largely precedes the main positive shifts in $\delta^{13} \mathrm{C}$ values.
[53] 2. Black shale beds do not correlate between sites 1050 and 1052, suggesting that local processes were responsible for the high organic matter content of these beds.

[54] 3. The $\delta^{18} \mathrm{O}$ gradient between thermocline-dwelling planktonic foraminifera and benthics is relatively stable in our records except for intervals where all planktonic species record values that converge with the benthics. This observation points to surface ocean control on organic matter accumulation.

[55] 4. On the other hand, the organic matter in the black shales is thought to be composed dominantly of highly degraded marine matter and/or terrestrial material [Barker et al., 2001] rather than immature type II organic matter typical of other OAE organic-rich deposits.

[56] 5. The episodes of increasing surface water productivity do not correlate with the intervals of organic matter accumulation.

[57] 6. Planktonic foraminiferal assemblages are relatively stable and show no apparent changes associated with intervals of black shale deposition, stable isotopic shifts, or organic carbon enrichment.

[58] Thus we cannot exclude the possibility that organic matter was transported downslope and/or was concentrated after a relatively long interval of degradation with warm deep water temperatures at Blake Plateau potentially enhancing preservation.

\section{Conclusions}

[59] Upper Albian organic-rich marls and black shales cored at ODP sites 1050 and 1052 on Blake Nose provide a well-preserved record of paleoceanographic, paleoclimatic, and biotic changes during a phase of black shale deposition. High-resolution correlation between the two sites is achieved using calcareous nannofossil and planktonic foraminiferal datums in combination with detailed $\delta^{13} \mathrm{C}$ stratigraphies obtained from benthic and planktonic foraminifera [Petrizzo and Huber, 2006; this study]. An interval of $\delta^{13} \mathrm{C}$ enrichment spanning the middle $P$. buxtorfi subzone through the lowermost Rotalipora globotruncanoides zone $(\sim 100.1$ to $99.6 \mathrm{Ma}$ ) is recognized at both sites and can be correlated with multiple sites in the North Atlantic [Nederbragt et al., 2001; Wilson and Norris, 2001] and western Tethys [Gale et al., 1996; Bornemann et al., 2005].

[60] This $\delta^{13} \mathrm{C}$ excursion is proposed as a means to consistently recognize OAE $1 \mathrm{~d}$, but note that black shale deposition in the North Atlantic seems to be decoupled from carbon isotope trends in the sections studied to date. That is, we have yet to identify a site of organic carbon burial that can be linked to the OAE $1 \mathrm{~d} \delta^{13} \mathrm{C}$ excursion.

[61] Paleobiological inferences based on the Blake Nose carbon and oxygen isotopic patterns suggest depth and seasonal preferences of a number of late Albian planktonic foraminifera. Specifically, we propose that (1) P. libyca and T. primula lived in the upper surface layer during peak summer, (2) B. breggiensis lived slightly deeper in the surface mixed layer or had spring and/or fall population maxima, (3) Hedbergella delrioensis, Hedbergella simplex, $R$. appenninica, and Rotalipora ticinensis lived below the seasonal thermocline, and (4) G. bentonensis, G. pulchellus, 
P. buxtorfi, $P$. praebuxtorfi, $P$. delrioensis, and $P$. stephani predominantly inhabited the thick winter mixed layer.

[62] Paleotemperature estimates from benthic foraminiferal $\delta^{18} \mathrm{O}$ values suggest that middle bathyal bottom water averaged $\sim 14^{\circ} \mathrm{C}$ at Site 1050 and upper bathyal bottom water averaged $\sim 17^{\circ} \mathrm{C}$ at Site 1052 during the late Albian, while paleotemperature estimates for surface-dwelling planktonic foraminifera range from $26^{\circ} \mathrm{C}$ to $31^{\circ} \mathrm{C}$ at both sites. Several variations are observed within the $R$. appenninica zone, reflecting reduced vertical stratification and differences in the vertical stratification between the two sites, which are located $30 \mathrm{~km}$ from each other. However, major perturbations in the Blake Nose stable isotope records occurred within the $800 \mathrm{ka}$ long interval preceding the onset of the OAE $1 \mathrm{~d} \delta^{13} \mathrm{C}$ shift (at $100.1 \mathrm{Ma}$ ) in the lower part of the $R$. appenninica zone. The most significant paleoceanographic changes inferred from these records include (1) evidence for shoaling of the thermocline at upper bathyal depths (Site 1052) between 100.9 and 100.7 Ma at the same time the entire water column episodically cooled in deeper waters (Site 1050) and (2) pronounced vertical mixing that caused collapse of the upper ocean thermal gradient and warming of the deep water at 100.4 Ma and may have been related to the coincident appearance of $P$. libyca and extinction of $B$. breggiensis. These differences in water mass stratification between Site 1052, whose paleodepth was about $500 \mathrm{~m}$, and Site 1050, whose paleodepth was about 1500 , can be understood in terms of changes in local oceanographic circulation arising from migration of a protowestern boundary current along the continental margin analogous to the modern Gulf Stream.

[63] On the basis of our data, and from our understanding of the carbon isotope record in the Vocontian basin, we confirm OAE 1d to be a global event, but we observe that black shale deposition at Blake Nose is controlled by local depositional patterns and changes of regional oceanographic conditions. Moreover, since black shale deposition on Blake Nose predates the $\delta^{13} \mathrm{C}$ excursion and there are no corresponding changes in organic matter accumulation, biotic diversity, or vertical water mass stratification, we cannot determine what processes drove the global carbon isotope anomaly.

[64] Acknowledgments. This research used samples and data provided by the Ocean Drilling Program (ODP). ODP is sponsored by the U.S. National Science Foundation (NSF) and participating countries under management of Joint Oceanographic Institutions (JOI), Inc. We are thankful to J. Erbacher, to R. K. Norris, and to the Editor, E. Rohling, for their constructive comments and suggestions. Funding for this project was provided by a Smithsonian Institution Postdoctoral Fellowship and a MIUR-PRIN 2005 to M.R.P. and a Smithsonian Walcott Fund grant to B.T.H. and NSF funding to K.G.M.

\section{References}

Arthur, M. A., S. O. Schlanger, and H. C. Jenkyns (1987), The Cenomanian-Turonian oceanic anoxic event II: Paleoceanographic controls on organic matter production and preservation, in Marine Petroleum Source Rocks, edited by J. Brooks and A. Fleet, Geol. Soc. Spec. Publ., 24, 399-418

Arthur, M. A., H.-J. Brumsack, H. C. Jenkyns, and S. O. Schlanger (1990), Stratigraphy, geochemistry, and paleoceanography of organic carbon rich Cretaceous sequences, in Cretaceous Resources, Events, and Rhythms, edited by R. N. Ginsburg and B. Beaudoin, pp. 75-119, Kluwer Acad., Norwell, Mass.

Barker, C. E., M. Pawlewicz, and E. A. Cobabe (2001), Deposition of sedimentary organic matter in black shale facies indicated by the geochemistry and petrography of highresolution samples, Blake Nose, western North Atlantic, in Western North Atlantic Palaeogene and Cretaceous Palaeoceanography, edited by D. Kroon et al., Geol. Soc. Spec. Publ., 183, 49-72.

Barron, E. J., and W. H. Peterson (1990), MidCretaceous ocean circulation: Results from model sensitivity studies, Paleoceanography, 5, 319-337.

Bellier, J.-P., M. Moullade, and B. T. Huber (2000), Mid-Cretaceous planktonic foraminifers from Blake Nose: Revised biostratigraphic framework [Online] Proc. Ocean Drill. Program Sci. Results, 171B. (Available at http://www-odp.tamu.edu/publications/ 171B SR/chap 03/chap 03.htm)

Bemis, B. E., H. J. Spero, J. Bjima, and D. W. Lea (1998), Reevaluation of the oxygen isotopic composition of planktonic foraminifera: Experimental results and revised paleotem- perature equations, Paleoceanography, 13 $150-160$.

Bornemann, A., J. Pross, K. Reichelt, J. O. Herrle, C. Hemleben, and J. Mutterlose (2005), Reconstruction of short-term palaeoceanographic changes during the formation of the Late Albian 'Niveau Breistoffer' black shales (oceanic anoxic event 1d, SE France), J. Geol. Soc., 162, 623-639.

Bralower, T. J., and H. R. Thierstein (1984), Low productivity and slow deep-water circulation in mid-Cretaceous oceans, Geology, 12, 614-618.

Bralower, T. J., M. A. Arthur, R. M. Leckie, W. V. Sliter, D. Allard, and S. O. Schlanger (1994), Timing and paleoceanography of oceanic dysoxia/anoxia in the late Barremian to early Aptian, Palaios, 9, 335-369.

Bréhéret, J.-G. (1988), Episodes de sedimentation riche en matiére organique dans les marnes bleues d'age aptien-albien de la partie pélagique du basin vocontien, Bull. Soc. Geol. Fr. 8, 349-356.

Bréhéret, J.-G. (1997), L'Aptien et l'Albien de la Fosse vocontienne (des bordures au basin) Evolution de la sedimentation et enseignements sur les événements anoxiques, Ann. Soc. Geol. Nord., 25, 614 pp.

Buzas, M. A., and L. A. C. Hayek (1998), SHE analysis for biofacies identification, J. Foraminiferal Res., 28, 233-239.

Clarke, L. J., and H. C. Jenkyns (1999), New oxygen isotope evidence for long-term Cretaceous climatic change in the Southern Hemisphere, Geology, 27, 699-702.

Coccioni, R. (2001), The "Pialli Level" from the latest Albian on the Umbria-marche Apennines (Italy), paper presented at Geoitalia
2001, Fed. Ital. di Sci. della Terra, Chieti, Italy.

Deroo, G., J. P. Herbin, and J. Roucache (1984), Organic geochemistry of Cenozoic and Mesozoic sediments from Deep Sea Drilling sites 544 to 547 , Leg 79, eastern North Atlantic, Initial Rep. Deep Sea Drill. Proj., 79, $721-741$

Deuser, W. G., and E. H. Ross (1989), Seasonally abundant planktonic foraminifera of the Sargasso Sea: Succession, deep-water fluxes, isotopic compositions, and paleoceanographic implications, J. Foraminiferal Res., 19, 268-293.

D'Hondt, S., and M. A. Arthur (1995), Interspecies variation in stable isotopic signals of Maastrichtian planktonic foraminifera, Paleoceanography, 10, 123-135.

Emiliani, C. (1954), Depth habitats of some species of pelagic foraminifera as indicated by oxygen isotope ratios, Am. J. Sci., 252, $149-158$.

Erba, E., I. Premoli Silva, and D. K. Watkins (1995), Cretaceous calcareous plankton biostratigraphy of sites 872 through 879 , Proc. Ocean Drill. Program Sci. Results, 144, $157-169$.

Erbacher, J., and J. Thurow (1997), Influence of anoxic events on the evolution of midCretaceous radiolaria in the North Atlantic and western Tethys, Mar. Micropaleontol., 30, 139-158.

Erbacher, J., J. Thurow, and R. Littke (1996), Evolution patterns of radiolaria and organic matter variations: A new approach to identify sea-level changes in mid-Cretaceous pelagic environments, Geology, 24, 499-502.

Erbacher, J., B. T. Huber, R. D. Norris, and M. Markey (2001), Increased thermohaline 
stratification as a possible cause for an oceanic anoxic event in the Cretaceous period, Nature, 409, 325-327.

Fairbanks, R. G., P. H. Wiebe, and A. W. H. Bé (1980), Vertical distribution and isotopic composition of living planktonic foraminifera in the western North Atlantic, Science, 207 $61-63$.

Fairbanks, R. G., M. Sverdlove, R. Free, P. H. Wiebe, and A. W. H. Bé (1982), Vertical distribution and isotopic fractionation of living planktonic foraminifera from the Panama $\mathrm{Ba}-$ sin, Nature, 298, 841-844.

Gale, A. S., W. J. Kennedy, J. A. Burnett, M. Caron, and B. E. Kidd (1996), The late Albian to early Cenomanian succession nea Rosans (Drome, SE France): An integrated study (ammonites, inoceramids, planktonic Foraminifera, nannofossils, oxygen, and carbon isotopes), Cretaceous Res., 17, 515-606.

Georgescu, M. D., and B. T. Huber (2006), Paracostellagerina nov. gen.: A meridionally costellate planktonic foraminiferal genus of the middle Cretaceous (latest Albian-earlies Cenomanian), J. Foraminiferal Res., 36, $368-373$

Giraud, F., D. Oliviero, F. Baudin, S. Reboulet, B. Pittet, and O. Proux (2003), Minor changes in surface-water fertility across the oceanic anoxic event 1d (latest Albian, SE France) evidenced by calcareous nannofossils, Int. J. Earth Sci., 92, 267-284, doi:10.1007/s00531003-0319-x.

Gradstein, F. M., J. G. Ogg, and A. G. Smith (Eds.) (2004), A Geologic Time Scale 2004 589 pp., Cambridge Univ. Press, New York.

Hay, W. W., et al. (1999), Alternative global Cretaceous paleogeography, in Evolution of the Cretaceous Ocean-Climate System, edited by E. Barrera et al., Spec. Pap. Geol. Soc. Am., $332,1-47$.

Herrle, J. O., J. Pross, O. Friedrich, P. Koszler, and C. Hemleben (2003), Forcing mechanism for mid-Cretaceous black shale formation: Evidence from the upper Aptian and lower Albian of the Vocontian Basin (SE France) Palaeogeogr. Palaeoclimatol. Palaeoecol. 190, 399-426.

Hofmann, P., W. Ricken, R. L. Schwaek, and D. Leythaeuser (2000), Carbon-sulfur-iron relationship in $\delta^{13} \mathrm{C}$ of organic matter from late Albian sedimentary rocks from the North Atlantic Ocean: Paleoceanographic implications, Palaeogeogr. Palaeoclimatol. Palaeoecol., 163, 97-113.

Huber, B. T., D. A. Hodell, and C. P. Hamilton (1995), Middle-Late Cretaceous climate of the southern high latitudes: Stable isotopic evidence for minimal equator-to-pole thermal gradients, Geol. Soc. Am. Bull., 107, 1164-1191.

Huber, B. T., R. D. Norris, and K. G. MacLeod (2002), Deep-sea paleotemperature record of extreme warmth during the Cretaceous, Geology, 30, 123-126.

Hut, G. (1987), Stable isotope reference samples for geochemical and hydrological investigations, in Report on Consultants' Meeting, Vienna, 16-18 September 1985, 42 pp., Int At. Energy Agency, Vienna.

Isaza-Londoño, C., K. G. MacLeod, and B. T. Huber (2006), Maastrichtian North Atlantic warming, increasing stratification, and foraminiferal paleobiology at three timescales, Paleoceanography, 21, PA1012, doi:10.1029/ 2004PA001130.
Jenkyns, H. C., and P. A. Wilson (1999), Stratigraphy, paleoceanography, and evolution of Cretaceous Pacific guyots: Relics from a greenhouse Earth, Am. J. Sci., 299, 341-392.

Leckie, R. M. (1984), Mid-Cretaceous planktonic foraminiferal biostratigraphy off central Morocco, Deep Sea Drilling Project Leg 79, sites 545 and 547, Initial Rep. Deep Sea Drill Proj., 79, 579-620

Leckie, R. M., T. J. Bralower, and R. Cashman (2002), Oceanic anoxic events and plankton evolution: Biotic response to tectonic forcing during the mid-Cretaceous, Paleoceanography, 17(3), 1041, doi:10.1029/2001PA000623.

Nederbragt, A. J., A. Fiorentino, and B. Klosowska (2001), Quantitative analysis of calcareous microfossils across the Albian-Cenomanian oceanic anoxic event at DSDP Site 547 (North Atlantic), Palaeogeogr. Palaeoclimatol. Palaeoecol., 166, 401-421.

Norris, R. D., and P. A. Wilson (1998), Lowlatitude sea-surface temperatures for the midCretaceous and the evolution of planktic foraminifera, Geology, 26, 823-826.

Norris, R. D., et al. (1998), Blake Nose palaeoceanographic transect, western North Atlantic, Proc. Ocean Drill. Program Initial Rep. $171 B, 1-749$

Norris, R. D., K. L. Bice, E. A. Magno, and P. A. Wilson (2002), Jiggling the tropical thermostat in the Cretaceous hothouse, Geology, 30 $299-302$.

Ogg, J. G., and L. Bardot (2001), Aptian through Eocene magnetostratigraphic correlation of the Blake Nose transect (Leg 171B): Florida continental margin [Online], Proc. Ocean Drill. Program Sci. Results, 171B. (Available at http://www-odp.tamu.edu/publications/ 171B_SR/chap_09/chap_09.htm)

Pedersen, T. F., and S. E. Calvert (1990), Anoxia vs. productivity: What controls the formation of organic-carbon-rich sediments and sedimentary rocks?, AAPG Bull., 74, 454-466.

Petrizzo, M. R., and B. T. Huber (2006), Biostratigraphy and taxonomy of late Albian planktonic foraminifera from ODP Leg 171B (western North Atlantic Ocean), J. Foraminiferal Res., 36, 165-189.

Poulsen, C. J., E. J. Barron, C. C. Johnson, and P. J. Fawcett (1999), Links between major climatic factors and regional oceanic circulation in the mid-Cretaceous, in Evolution of the Cretaceous Ocean-Climate System, edited by E. Barrera et al., Spec. Pap. Geol. Soc. Am. $332,73-89$

Robaszynski, F., and M. Caron (1995), Foraminifères planctonique du Crétacé: Commentaire de la zonation Europe-Méditerranée, Bull. Soc. Geol. Fr. 166, 681-692.

Rohling, E. J., et al. (2004), Reconstructing past planktic foraminiferal habitats using stable isotope data: A case history for Mediterranean sapropel S5, Mar. Micropaleontol. $50,89-123$

Schlanger, S. O., and H. C. Jenkyns (1976), Cretaceous oceanic anoxic events: Causes and consequences, Geol. Mijnbouw, 55 , $179-184$.

Shackleton, N. J., and J. P. Kennett (1975), Paleotemperature history of the Cenozoic and the initiation of antartic glaciation: Oxygen and carbon isotope analyses in DSDP sites 277, 279, and 281, Initial Rep. Deep Sea Drill. Proj., 29, 743-755.

Shackleton, N. J., and E. Vincent (1978), Oxygen and carbon isotope studies in recent for- aminifera from the southwest Indian Ocean, Mar. Micropalaeontol., 3, 1-13.

Shannon, C. E. (1949), The mathematical theory of environments, in The Mathematical Theory of Communication, edited by C. E. Shannon and W. Weaver, pp. 1-93, Univ. of Ill. Press, Urbana.

Spero, H. J., J. Bijma, D. W. Lea, and B. E. Bemis (1997), Effect of seawater carbonate concentration of foraminiferal carbon and oxygen isotopes, Nature, 390, 497-500.

Strasser, A., M. Caron, and M. Gjermeni (2001), The Aptian, Albian and Cenomanian of Roter Sattel, Romandes Prealps, Switzerland: A high-resolution record of oceanographic changes, Cretaceous Res., 22, 173-199.

Thurow, J., H.-J. Brumsack, J. Rullkötter, R. Littke, and P. Meyers (1992), The Cenomanian/Turonian boundary event in the Indian Ocean-A key to understand the global picture, in Synthesis of Results From Scientific Drilling in the Indian Ocean, Geophys. Monogr. Ser., vol. 70, edited by R. A. Duncan et al., pp. 253-273, AGU, Washington, D. C.

Watkins, D. K., and J. A. Bergen (2003), Late Albian adaptive radiation in the calcareous nannofossil genus Eiffelithus, Micropaleontology, 49, 231-252.

Watkins, D. K., and J. M. Self-Trail (2005), Calcareous nannofossil evidence for the existence of the Gulf Stream during the late Maastrichtian, Paleoceanography, 20, PA3006, doi:10.1029/2004PA001121.

Watkins, D. K., M. J. Cooper, and P. A. Wilson (2005), Calcareous nannoplankton response to late Albian oceanic anoxic event $1 \mathrm{~d}$ in the western North Atlantic, Paleoceanography, 20, PA2010, doi:10.1029/2004PA001097.

Wefer, G., and W. H. Berger (1991), Isotope paleontology: Growth and composition of extant calcareous species, Mar. Geol., 100, 207-248.

Wilson, P. A., and R. D. Norris (2001), Warm tropical ocean surface and global anoxia during the mid-Cretaceous period, Nature, 412 , $425-429$.

Wilson, P. A., R. D. Norris, and M. J. Cooper (2002), Testing the Cretaceous greenhouse hypothesis using "glassy" foraminiferal calcite from the core of the Turonain tropics on Demerara Rise, Geology, 30, 607-610.

Zachos, J. C., L. D. Stott, and K. C. Lohmann (1994), Evolution of early Cenozoic marine temperatures, Paleoceanography, 9, 353-387.

Zeebe, R. E. (1999), An explanation of the effect of seawater carbonate concentration on foraminiferal oxygen isotopes, Geochim. Cosmochim. Acta, 63(13-14), 2001-2007.

B. T. Huber, Department of Paleobiology, MRC NHB 121, Smithsonian Museum of Natural History, Washington, DC 20013-7012, USA

K. G. MacLeod, Department of Geological Sciences, University of Missouri, Columbia, MO 65211, USA.

M. R. Petrizzo, Dipartimento di Scienze della Terra "Ardito Desio", Università di Milano, via Mangiagalli 34, I-20133, Milan, Italy.

P. A. Wilson, National Oceanography Centre, Southampton, School of Ocean and Earth Science, European Way, Southampton SO14 3ZH, UK. 